\title{
1. INTRODUCTION AND EXPLANATORY NOTES
}

\author{
Shipboard Scientific Party ${ }^{1}$
}

\section{SCIENTIFIC OBJECTIVES}

Leg 42A of the Deep Sea Drilling Project was scheduled to continue the geological exploration of the Mediterranean (Figure 1). The 1970 drilling during Leg 13 discovered the basin-wide occurrence of a Messinian evaporite formation. Studies of the drill cores also yielded considerable information on the Messinian salinity crisis and on the Plio-Quaternary history of this inland sea. However, this first Deep Sea Drilling cruise to the Mediterranean was designed as a reconnaissance. A total of 14 sites were drilled east of Gibraltar, and in most of those we failed to penetrate deeper than the Plio-Quaternary, or the upper Messinian. Little information was gathered on the pre-Messinian history of the Mediterranean. The lack of such data was particularly vexing because a definitive interpretation on the genesis of the Mediterranean Evaporite Formation depends upon a knowledge of the state of tectonic evolution of the Mediterranean prior to the Messinian salinity crisis.

The planning of the second Mediterranean cruise began in earnest in 1972 after a reorganization of the Mediterranean Advisory Panel. Marine geological and geophysical investigations of the Mediterranean were carried out mainly by the European organizations following the 1970 cruise. We relied heavily in our planning on the French I.F.P.-CNEXO data for sites in the Balearic and Levantine basins, on the Italian (Trieste and Bologna) data for sites in the Tyrrhenian and the Ionian basins, and on the German (Hannover) and British (Cambridge) data for Aegean sites. Valuable information was also made available to us by

${ }^{1}$ Kenneth J. Hsü (Co-chief scientist), Eidg. Technisches Hochschule, Geologisches Institut, Zurich, Switzerland; Lucien Montadert (Co-chief scientist), Division Geologie, Institut Francais du Petrole, Rueil Malmaison, France; Daniel Bernoulli, Geologisch-palaontologisches Institut der Universitat Basel, Basel, Switzerland; Germaine Bizon, Bureau d'Etudes Industrielles et de Cooperation de l'Institut Francais du Petrole, Rueil Malmaison, France; Maria Cita, Instituto di Geologia, Universita degli Studi di Milano, Milano, Italy; Al Erickson, Department of Geology, University of Georgia, Athens, Georgia; Frank Fabricius, Institut fur Geologie Techn. Universitat, Munich, Germany; Robert E. Garrison, University of California, Santa Cruz, California; Robert B. Kidd, Institute of Oceanographic Sciences, Wormley, United Kingdom; Frederic Mélières, Laboratoire de Geologie Dynamique, University of Paris, Paris, France; Carla Müller, Geologisch-Paleontologisches Instutut der Johann Wolfgang Geothe-Universitat, Frankfurt, Germany (Present address: Bureau d'Etudes Industrielles et de Cooperation de L'Institut Français du Petrole, Rueil Malmaison, France); Ramil C. Wright, Beloit College, Department of Geology, Beloit, Wisconsin (Present address: Department of Geology, The Florida State University, Tallahassee, Florida. colleagues based in Isreal, the Soviet Union, and in the United States. We are proud of the fact that the seed for IPOD was planted after the first Mediterranean cruise, when W. Nierenburg, then chairman of the JOIDES Executive Committee and head of the Deep Sea Drilling Project officially invited international participation during a post-cruise press conference at Paris on 9 October 1970. The international contact required by the planning for the second Mediterranean cruise did much to sustain the spirit of cooperation and mutual assistance, which has made the IPOD one of the most productive international scientific ventures.

Planning for the second Mediterranean drilling was restrained by two controlling factors: depth of penetration of a single-bit hole, and the safety aspects of drilling into an evaporite basin. Although a Mediterranean cruise had been initially scheduled for the latter part of the third phase of the DSDP drilling, it was almost abolished altogether in 1972 when scientists interested in other oceans questioned if useful information could be obtained by sending the Glomar Challenger east of Gibraltar for a second time. None was in favor of drilling another series of shallow bore holes penetrating only to the top of the Mediterranean Evaporite. It was not until the autumn of 1972 at a meeting in Zurich that the JOIDES Planning Committee was convinced that we could drill into pre-Messinian lithologies and could do so safely. The strategy was to search for areas where the Mediterranean Evaporite formation had been largely or completely removed by erosion (as at the eventual Sites 371, 372, 373, 375, 377 ) or areas where the evaporite did not form structures with closures that could trap hydrocarbons (as at Sites 374, 376, 378). The Mediterranean panel members met three times with the JOIDES Safety Panel. Extremely detailed site surveying was carried out by the I.F.P. before the drilling program was approved.

The main scientific objectives of the cruise were twofold: first, we intended to obtain information which would allow reconstruction of the tectonic evolution of the Mediterranean. This study should provide us with a key to an understanding of the birth and demise (through orogeny) of small ocean basins, which have been referred to as geosynclines in classical geological literature. For this purpose we needed to sample the basement underlying the oldest sediments of the Mediterranean in order to determine its age and composition so that we could interpret its origin. Holes 371 and $373 \mathrm{~A}$ were scheduled mainly for this purpose. Unfortunately we had to stop short of basement in Hole 371 because of a ruling by the Safety Panel. We were 


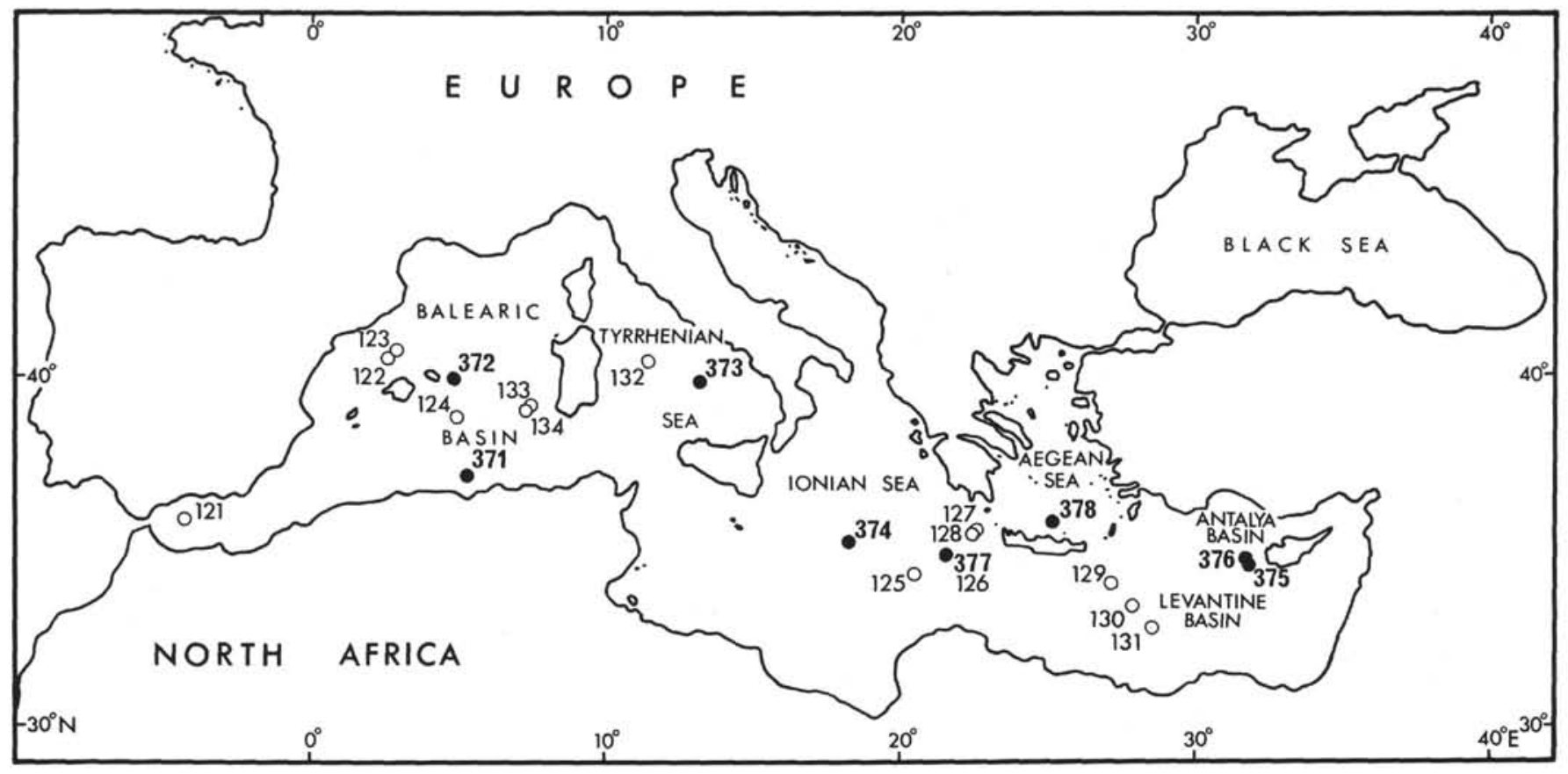

Figure 1. Map of Mediterranean with Leg $42 \mathrm{~A}$ sites shown in relation to Leg 13 sites.

successful in penetrating almost 200 meters into basalt in Hole 373A under the Tyrrhenian Abyssal Plain.

Our second main objective was to obtain information necessary for a definitive interpretation of the history of the Messinian Salinity Crisis. Again we were required to drill into the pre-Messinian sediment sequences in order to study their depositional environments, their paleobiogeographical province, and their geologic history. We accomplished those objectives by drilling Holes 372,375 , and 377 . We also needed to have continuously cored sections of the Mediterranean Evaporite Formation to study the evolution of the salinity crisis itself. These continuous sections were obtained at Sites 374 and 376. In addition we planned to explore a Mediterranean basin hitherto undrilled, namely the Aegean in order to precisely determine the extent of the evaporite formation. Consequently Site 378 was drilled in the Cretan Basin.

Naturally, all sites had multiple objectives. This assignment of main goals serves to focus the attention of readers who might wish to look for specific information in this volume.

An additional scientific objective of our cruise was to conduct geothermal studies. The heat-flow measurements during several previous DSDP legs had not been particularly successful. The Mediterranean DSDP holes should be more suitable than open ocean holes for such studies. The firm, but not hard, Plio-Quaternary sediments are thick enough to enable the penetration and stabilization of the heat-flow probe down to a few hundred meters below the sea floor, where the temperature gradient should remain undisturbed by shortterm thermal events. Furthermore, the weather in this inland sea could be, as eventually proved to be the case, ideal (namely, little wind and low swells) for the operations involved in making geothermal measure- ments. We hoped that the heat-flow values would provide additional information with which to unravel the complicated history of the Mediterranean Sea. During Leg 42A successful heat-flow measurements were made at Sites 372, 373, 374, 376, and 378. They represent to date one of the best sets of heat-flow values ever measured from beneath the ocean floor.

Another advantage of drilling in the Mediterranean is that the usefulness of the deep-sea data could be maximized through a comparison of the deep-sea record with the record on land, where the geology has been thoroughly investigated. We are including in this volume three sets of comparative geological studies: between Site 372 and the Balearic Islands, between Site 374 and the Ionian Islands, and between Sites 375/376 and Cyprus. Our synthesis chapters also made extensive use of the geological data of the circumMediterranean region.

\section{CRUISE NARRATIVE}

Glomar Challenger left Malaga in the early morning hours of 4 April 1975 and arrived at Istanbul at about noon, 21 May. During the 5 weeks at sea, 11 holes were drilled at 8 sites (Figure 1). Some 4500 meters of stratigraphic section were penetrated, and the oldest formation reached was the lower Miocene (Figure 2).

On 16 April, we started to drill our first hole at Site 371 in the South Balearic Basin. The objective was to sample basement on a structural high where the evaporite cover should have been removed by erosion. The basement topography under the site was rugged and precise positioning was difficult. The drill site was eventually located 1.3 sea miles east and down the basement slope from the original target location. This offset necessitated slow drilling through the semiconsolidated Pliocene marls. Also it was located on the flank 
of the structure where the Messinian Evaporite is present. We had to terminate the hole before reaching the basement objective in accordance with constraints set by the JOIDES Safety Panel. We were disappointed that we could not obtain a sample of the basement, which is probably basaltic as suggested by the high magnetic anomalies associated with the structure. As a consolation, we did retrieve useful information concerning the genesis of the Mediterranean Evaporite.

Glomar Challenger approached Site 372 on the Menorca Rise at midnight of 18 April. Again we required precise positioning in order to achieve our multiple objectives. The approach was made difficult by strong winds and by currents of unknown velocity, but we did reach an optimum position after a 7-hour search. The operations at this site were successful. We drilled through a thin edge of the Mediterranean Evaporite and penetrated 885 meters into the Burdigalian sediments. Both the Plio-Quaternary and the preMessinian deposits are deep marine, hemipelagic sediments. The Messinian consists of interbedded gypsum and marls. Drilling at this site dated the initial rifting of the Balearic margin as earliest Miocene or late Oligocene. Paleo-bathymetric analyses of pre-Messinian sediments confirmed previous interpretations that a deep basin was in existence prior to the salinity crisis. An offset, Hole 372A, was made for heat-flow measurements. There high heat-flow values were measured, as we had expected in view of the Neogene age of the basin.

After a little more than 5 days at Site 372, Glomar Challenger left at noon, 24 April, for the Tyrrhenian Sea. We reached Site 373 on the morning of 27 April. We planned to drill on the flank of a seamount, where the soft Plio-Quaternary sediments would be thick enough to bury the bottom-hole assembly. However, it was very difficult to determine the precise depth to the sea floor from the PDR because of numerous side echoes on the record. Our first hole was placed too high on the flank of the seamount, since there the drill string encountered hard rock after penetrating only a few meters of soft sediments. It had to be abondoned therefore for technical reasons, and an offset was made to a position further down the flank of the seamount. We achieved our objectives at Hole 373A. After drilling through a thin Plio-Quaternary cover, the hole penetrated 187 meters into the basalt basement. By confirming that this Tyrrhenian seamount, marked by magnetic anomalies, is underlain by oceanic tholeiites, we atoned for our failure to sample the buried Balearic seamount at Site 371. Shore-base age-dating yielded a late Miocene age for the oldest Tyrrhenian basalt sample, indicating that a deep basin was in existence prior to the salinity crisis. High heat-flow values were recorded at this site which again is in accordance with the very young age of the basin.

After passing to the Eastern Mediterranean via the Messina Strait, Glomar Challenger arrived, in the afternoon of 1 May at a location above the central Messinian Abyssal Plain. Precise positioning was not necessary at Site 374 . The drill string penetrated the base of the datable Pliocene at 373 meters subbottom, where we encountered a dolomite which may represent diagenetically altered sediment of earliest Pliocene age. The latest Messinian sediments are not evaporites, but a series of largely unfossiliferous dolomitic muds and marls. We encountered gypsum at $\mathbf{4 0 6 . 5}$ meters subbottom topping a unit of cyclically deposited evaporitic sediments.

At 0925 LCT 3 May while drilling through the evaporites at Site 374, we experienced a mysterious anomaly in the apparent positioning of the vessel. The monitoring of the weight on drill bit suggested that the ship was apparently far off location, but all bridge and computer-room equipment showed that excursions could not have been in excess of 30 meters. This anomaly, as we shall discuss later, was also observed when we drilled through the evaporite section at Site 375. At 1705 LCT 3 May, we pulled up a core which contained halite and potash salts confirming the anticipated "bull's eye" distribution of Messinian saline minerals below this abyssal plain. Two further attempts to retrieve salt failed; we suspect that salts more soluble than halite were being penetrated. Since we had now penetrated more than 40 meters beneath the strong gypsum reflector, we had to terminate the hole in accordance with constraints set by the JOIDES Safety Panel. Operations were completed after 3 days on site, and the vessel departed in the morning of 4 May for Site 375 west of Cyprus.

Sites 375 and 376 constitute a short traverse across the Cyprus Arc from the Florence Rise to the Antalya Basin. We had high hopes for Hole 375, where we thought we might have had an outside chance of reaching an ophiolitic basement. For this very important objective, we targeted 7 to 10 days and our planning was based upon our estimate of the longevity of single drill bits as suggested by the experience of previous Leg 40 drilling. The vessel was positioned over the hole at 1705 LCT 7 May. We had hoped that the Messinian was absent at this site, but we were soon to experience surprise and anxiety. The first reflector was met at 137.5 meters subbottom, and Core 1 was found to contain a Pliocene marine ooze on top of Messinian marls and gypsum. Furthermore, the drilled section between 137.5 and 170 meters must have been mainly gypsum (and/or anhydrite). We were concerned about wear and tear on the drill bit and also anxious for our safety as it ground its way slowly through the hard formation.

At 0334 LCT 8 May, the drill string suddenly penetrated into a very soft horizon, at 172 meters subbottom. The monitoring of bit weight again suggested that the vessel had wandered off location. However, it was ascertained, after a check of all systems, that there had been no drift whatsoever. The mysterious positioning anomaly was reminiscent of our experience at Site 374. Meanwhile the driller may have "overfed" the pipe when the monitor showed this sudden loss of bit weight. The overfeeding caused the drill pipe to become dented at the mudline, as we found out later when the drill string was pulled out. 
Tortonian marls were sampled when Core 4 (cut between 245.5-252 m subbottom) was retrieved. Meanwhile, we were advised that we should spot-core in order to save wear on the bearings of the drill bit and thus prolong the life of the bit. Cores were taken at about 100-meter intervals until 574.5 meters subbottom. Since by now we had drilled into stiff marls of Serravalian age, we had to raise the barrel at shorter and shorter coring intervals. Also all the pre-Messinian cores contained gas. We were permitted to drill ahead as the methane/ethane ratio was 1000 or more. Just after penetrating a Langhian limestone at 675.5 meters we were witnesses to an exciting spectacle reminiscent of a "derrick blowout," but we soon realized with relief that this apparent catastrophe was caused by a broken rotary hose. After a Burdigalian core was cut from 817.5 to 821.5 meters subbottom and raised on deck, it was found that the hole diameter had become so small that the bottom-hole assembly was becoming jammed. Reluctantly we had to abandon the hole. We were still far from the basement, but had uncovered a section that is practically identical to the coeval land section on Cyprus. This discovery made us confident that we could use the information from the island to interpret the geology of this part of the Mediterranean.

Glomar Challenger arrived at Site 376 at 1820 LCT 10 May. We drilled through the marine Plio-Quaternary, and found below a thick section of euryhaline Messinian deposits. The drill string hit the gypsum reflector at 134 meters subbottom and went through some very hard drilling before a halite core was raised from 207 meters subbottom depth. At 1230 LCT 12 May while the salt core was being cut, there was a sudden loss of pump pressure. Various possibilities that might have caused the loss (such as a defective pump, etc.) were ruled out. Our operations manager was convinced that we had drilled into a zone of "lost circulation," probably a cavernous zone where the Messinian evaporites were partly leached out. We now realized that drilling into caverns might also have been the cause of the mysterious positioning-anomalies we encountered when penetrating the evaporite sections of Sites 374 and 375 . The last core, which also contained halite, gave off a very strong odor of hydrocarbon. We decided to terminate drilling for safety reasons. Heatflow measurements were made at Site 376, and the low value measured confirm the old age of the basement there.

We were now faced with a dilemma. Our stay at the sites near Cyprus was cut short because of the drill bit failure at Site 375 and because of the safety considerations at Site 376. An originally targeted site on Eratosthenes Seamount could not be drilled because the sedimentary cover there was considered too thin to bury the bottom-hole assembly. It was still too early to sail to the Aegean. After considerable discussion, it was decided to turn back westward to redrill DSDP Site 126 on the Mediterranean Ridge. This was in the hope that we could now penetrate much deeper than in our first drilling attempt there 5 years ago, bearing in mind the considerable improvement in drilling equipment since that time.

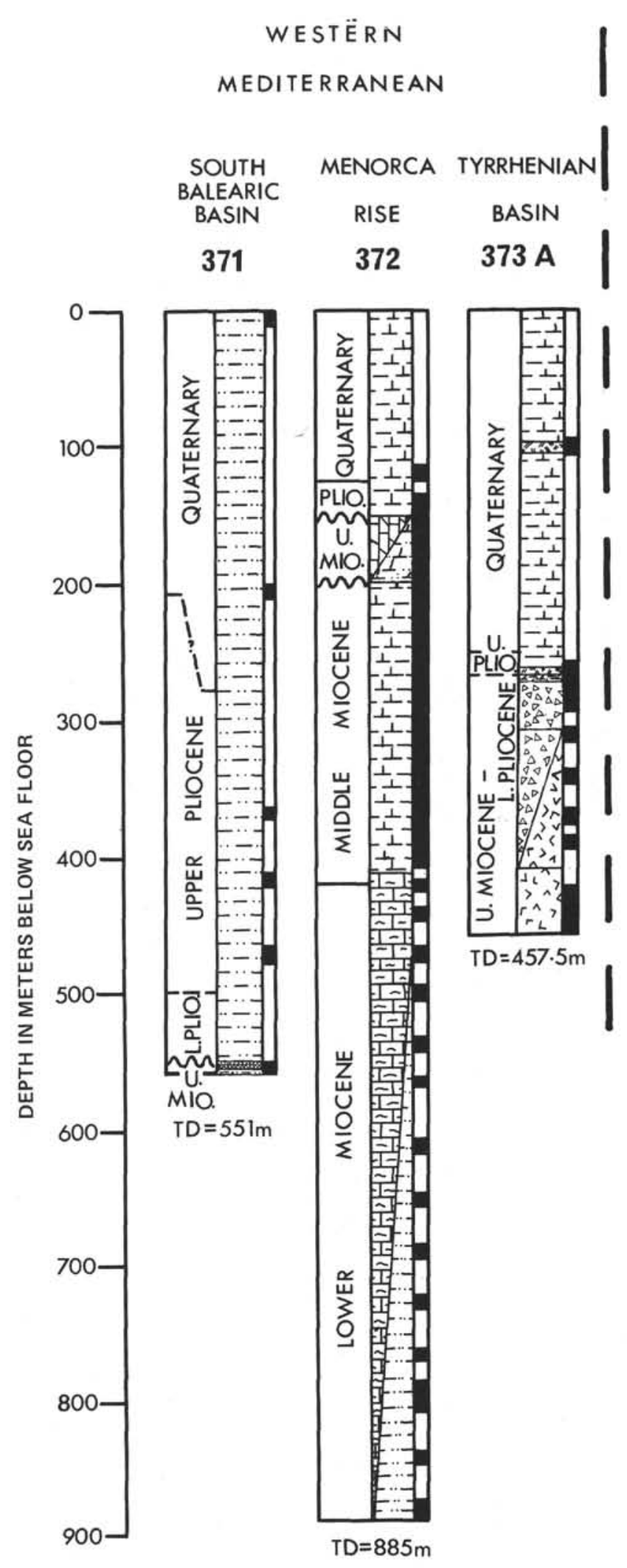

Figure 2. General stratigraphy of the Leg $42 \mathrm{~A}$ drill sites. 
EASTERN

MEDITERRANEAN

IONIAN MEDITERRANEAN

BASIN RIDGE CLEFT

CRETAN BASIN

FLORENCE RISE

374 377

378

378 A

375

376
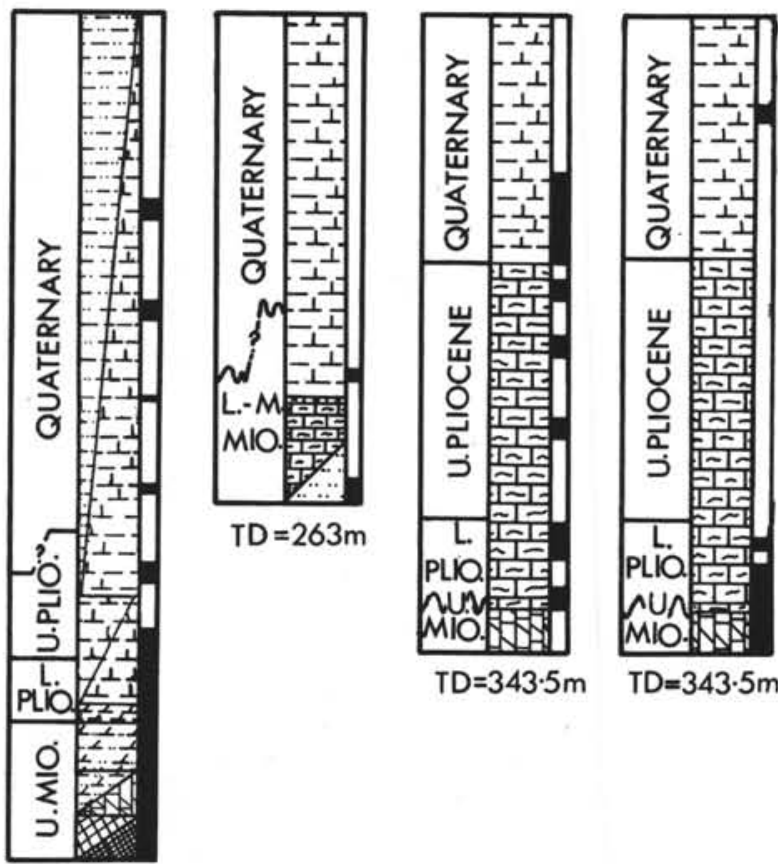

$\mathrm{TD}=343 \cdot 5 \mathrm{~m}$

$\mathrm{TD}=343.5 \mathrm{~m}$

$T D=457 \mathrm{~m}$

Cored

Interval
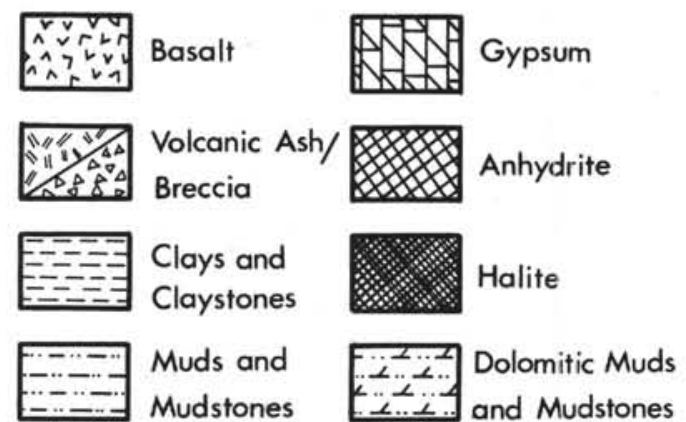

Nannofossil

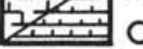
Oozes/Chalks

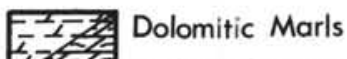

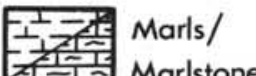

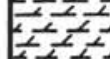

Dolomite/Dolomitic

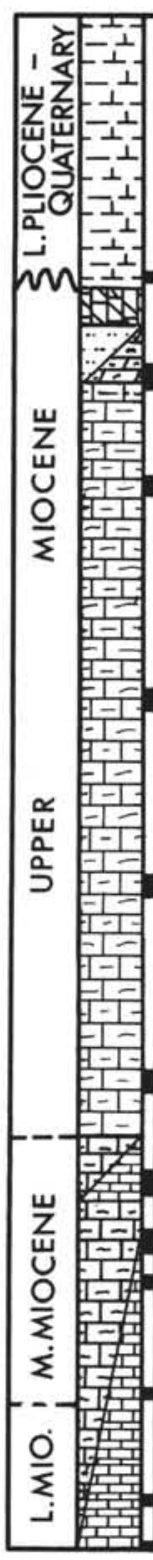

$T D=821.5 \mathrm{~m}$

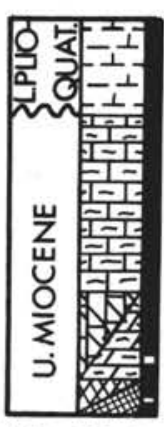

$T D=216.5 \mathrm{~m}$<smiles>CC(CO)C(=O)O[Na]</smiles>
Limestones

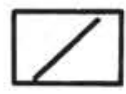

Interbedded Lithologies

Figure 2. (Continued). 
On the morning of 15 May Glomar Challenger reached Site 377 where a cleft cuts across the Mediterranean Ridge. In the cleft itself the Quaternary directly overlies pre-Messinian sediments. The hole penetrated into the middle Miocene after 1 day of drilling. However, drilling rate became very slow and we were drilling into poorly fossiliferous clastic sediments. We were forced to abandon the hole to save time for drilling at the Aegean site.

Site 378 was located in the north Cretan Basin. The vessel was positioned at 1730 LCT 17 May. After drilling through a marine Plio-Quaternary sequence, Holes 378 and 378A were terminated in Messinian selenitic gypsum. The operations were completed at Site 378 before 7 o'clock, 19 May, so that Glomar Challenger could make her port call at Istanbul at noon 21 May. We reached Istanbul on schedule.

During the 37 days at sea, Glomar Challenger traveled 3217 nautical miles, drilled 11 holes at 8 sites. In 150 attempts we cored 1192.2 meters and recovered 670 meters (or $30 \mathrm{~m}$ more than Leg 13 drilling with 54 days at sea). Water depth of the holes ranged from 1845 to 4090 meters. The maximum penetration was 885 meters at Site 372 . Total penetration was 4461.5 meters of stratigraphic section. (For full details, see Table 1.)

In retrospect, some of us might have missed the exhilaration and excitement of first discovery as experienced during the Leg 13 cruise. The task of this second drilling expedition was more somber and certainly more difficult. Nevertheless, we experienced our share of joy, anxiety, and sometimes of disappointment. In all, the scientific accomplishments of the cruise and its technical achievements were not inconsiderable. We did what could not be done 5 years ago; namely, to penetrate the Mediterranean Evaporite and establish a pre-Messinian history for the deep Mediterranean; and to sample oceanic basement in a Mediterranean basin.

\section{RESPONSIBILITIES FOR AUTHORSHIP}

Chapters 2 to 8 (Part I) of this volume present the basic shipboard data and discussions on the holes drilled during Leg 42A. The authorship of these site chapters is collectively that of the shipboard scientific party with ultimate responsibility lying with the cochief scientists, Ken Hsü and Lucien Montadert. Each was compiled by Robert B. Kidd, the Leg $42 \mathrm{~A}$ science coordinator and volume editor, to a standard format as listed below, with the respective authors of each section in parentheses

Site Summary Data

Background and Objectives (Montadert and Hsü)

Operations (Hsü and Montadert)

Site Approach

Drilling Program

Lithology(Kidd, Meliérès, Garrison, Fabricius, and Bernoulli)

Geochemical Measurements (Hsü and Fabricius)

Physical Properties (Erickson)

Biostratigraphy

Summary (Bizon and Müller)
Nannofossils (Müller)

Planktonic Foraminifers (Cita)

Planktonic Foraminifers (Bizon)

Benthic Foraminifers (Wright)

Sedimentation Rates (Kidd)

Correlation of Seismic Reflection Profiles with Drilling Results (Montadert)

Summary and Conclusions (Hsü and Montadert)

References

Hole Summary Diagram

Core Summary Forms

Core Photographs

The interpretations of individual authors have been retained in the section for which they were responsible. Consequently, conflicting interpretations are sometimes apparent between individual sections, or between a particular section and the summary and conclusions, the latter represent an attempt by the co-chief scientists at a consensus viewpoint. Authorship of papers dealing with special topics (Part II) and the Synthesis Chapters (Part III) is cited in the text. It should be pointed out here that the interpretations expressed in these individual contributions are those of their authors and in some cases to not reflect the views of the co-chief scientists and the remainder of the shipboard party. Although the shipboard scientists reviewed drafts of all manuscript, our policy was to allow complete "freedom of speech" in these parts of the volume. The chapters of Part IV, on the other hand again represent a consensus of the views of the shipboard party. The reader should note also that downhole heat-flow measurement, although a shipboard study, is reported by Erickson in Chapter 36 of Part II.

\section{SURVEY AND DRILLING DATA}

\section{Surveys}

The presite survey data, kindly supplied to the JOIDES Mediterranean Advisory Panel by the various organizations and institutions active in the area and on which the site selections were based, is acknowledged in the relevant site chapters.

A shipboard precision echo-sounder together with seismic profiling equipment, was used to determine specific site locations. These data are discussed in the sections dealing with site approach. En route between sites, continuous observations were made of depth, magnetic field intensity, and subbottom structure (see Appendix IV). Underway depths were recorded on a Gifft precision graphic recorder (PGR). The depths were read on the basis of an assumed 800 fathoms/sec sounding velocity. The sea depth (in $\mathrm{m}$ ) was corrected (1) according to the tables of Matthews (1939) and (2) for the depth of the hull transducer, 6 meters below sea level. In addition, any depths referred to the drilling platform have been calculated under the assumption that this level is 10 meters above the water line.

The seismic profiling system aboard Glomar Challenger consisted of two Bolt airguns, a Scripps-designed hydrophone array, Bolt amplifiers, two bandpass filters 
TABLE 1

Coring Summary

\begin{tabular}{|c|c|c|c|c|c|c|c|c|c|c|}
\hline Hole & $\begin{array}{l}\text { Dates } \\
(1975)\end{array}$ & Latitude & Longitude & $\begin{array}{l}\text { Water } \\
\text { Depth } \\
\text { (m) }\end{array}$ & $\begin{array}{l}\text { Penetration } \\
(\mathrm{m})\end{array}$ & $\begin{array}{l}\text { No. of } \\
\text { Cores }\end{array}$ & $\begin{array}{l}\text { Meters } \\
\text { Cored }\end{array}$ & $\begin{array}{c}\text { Meters } \\
\text { Recovered }\end{array}$ & $\begin{array}{c}\% \\
\text { Recovery }\end{array}$ & $\begin{array}{c}\text { Oldest } \\
\text { Sediment }\end{array}$ \\
\hline $\begin{array}{l}371 \\
372 \\
372 \mathrm{~A}\end{array}$ & $\begin{array}{l}\text { 16-18 Apr. } \\
\text { 19-24 Apr. } \\
\text { 24-25 Apr. }\end{array}$ & $\begin{array}{l}37^{\circ} 01.88^{\prime} \mathrm{N} \\
40^{\circ} 01.86^{\prime} \mathrm{N} \\
40^{\circ} 01.90^{\prime} \mathrm{N}\end{array}$ & $\begin{array}{l}05^{\circ} 14.55^{\prime} \mathrm{E} \\
04^{\circ} 47.79^{\prime} \mathrm{E} \\
04^{\circ} 47.79^{\prime} \mathrm{E}\end{array}$ & $\begin{array}{l}2792 \\
2699 \\
2695\end{array}$ & $\begin{array}{l}551.0 \\
885.0 \\
154.5\end{array}$ & $\begin{array}{r}8 \\
46 \\
0\end{array}$ & $\begin{array}{l}62.0 \\
431.0 \\
\text { Drilled }\end{array}$ & $\begin{array}{c}43.3 \\
315.9 \\
\text { for heat flow }\end{array}$ & $\begin{array}{l}70.0 \\
73.3\end{array}$ & $\begin{array}{l}\text { Upper Miocene } \\
\text { Lower Miocene }\end{array}$ \\
\hline 373 & $\ldots \ldots$ & . & 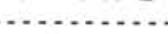 & $\ldots .$. & Not Drilled & $\ldots$ & - & . & & \\
\hline $373 \mathrm{~A}$ & 27-29 Apr. & $39^{\circ} 43.68^{\prime} \mathrm{N}$ & $12^{\circ} 59.56^{\prime} \mathrm{E}$ & 3517 & 457.5 & 12 & 114.0 & 27.5 & 24.1 & Lower Pliocene \\
\hline 374 & 1-4 May & $35^{\circ} 50.87 ’ \mathrm{~N}$ & $18^{\circ} 11.78^{\prime} \mathrm{E}$ & 4078 & 457.0 & 24 & 153.5 & 77.2 & 50.3 & Upper Miocene \\
\hline 375 & 7-10 May & $34^{\circ} 45.74^{\prime} \mathrm{N}$ & $31^{\circ} 45.58^{\prime} \mathrm{E}$ & 1900 & 821.5 & 13 & 73.0 & 66.9 & 91.6 & Lower Miocene \\
\hline 376 & 10-12 May & $34^{\circ} 52.32^{\prime} \mathrm{N}$ & $31^{\circ} 48.45^{\prime} \mathrm{E}$ & 2101 & 216.5 & 23 & 202.5 & 76.4 & 37.7 & Upper Miocene \\
\hline 377 & 15-16 May & $35^{\circ} 09.25^{\prime} \mathrm{N}$ & $21^{\circ} 25.86^{\prime} \mathrm{E}$ & 3718 & 263.0 & 4 & 10.0 & 8.2 & 82.0 & Middle Miocene \\
\hline 378 & 17-18 May & $35^{\circ} 55.67 ’ \mathrm{~N}$ & $25^{\circ} 06.97 ’ \mathrm{E}$ & 1835 & 312.0 & 11 & 100.2 & 34.8 & 34.7 & Lower Pliocene \\
\hline $378 \mathrm{~A}$ & 18-19 May & $35^{\circ} 55.67^{\prime} \mathrm{N}$ & $25^{\circ} 06.97^{\prime} \mathrm{E}$ & 1835 & 343.5 & 9 & 46.0 & 20.0 & 43.5 & Upper Miocene \\
\hline Total & & & & & 4461.0 & 150 & 1192.2 & 670.2 & 56.2 & \\
\hline
\end{tabular}

and two EDO recorders, usually recording at two different filter settings.

\section{Drilling Characteristics}

The taking of cores in a particular hole may be continuous, but more often is interspersed by drilled, but uncored, intervals of variable length (spot coring).

Due to circulation of water down the hole, drill cuttings are flushed out of the hole onto the sea bed (an "open system") and cannot be examined.

The only information available about sedimentary material between cores, other than from seismic data, is from an examination of the behavior of the drill string as observed on the drill platform. The harder the layer being drilled, the slower and more difficult it is to penetrate. The most prominent of such layers are known as "drill breaks." There are, however, a number of other factors which determine the rate of penetration, so it is not possible to relate this directly to the hardness of the layers. The following parameters are recorded on the drilling recorder, and all influence the rate of penetration.

1) Weight on the bit. This can vary in three steps from zero, when the bit is suspended above the bottom of the hole to 40,000 pounds when two of the three bumper subs are collapsed and the whole bottom assembly bears on the bit. The aim of the driller, is, by reference to the weight indicator, to maintain constant bit weight by lowering the drill string when necessary. However, this is extremely difficult to do in conditions of swell, when the heave of the drill platform may exceed the avalable extention (6 ft) of the bumper subs.

2) Revolutions per minute. The revolutions per minute (rpm) are related to the torque applied to the top of the drill string, and a direct analysis of the two should give the resistance to drilling. However, the rpm record is not detailed enough to do this. Nevertheless, visual observations of the rate of drill string rotation are useful in assessing bit behavior. In particular, it can be seen that when the drill bit becomes jammed in very resistant rock; rotation stops, the bit becomes free and the drill string untwists.

\section{Drilling Disturbance}

Most cores, when split and examined aboard Glomar Challenger, show signs of having been disturbed to a greater or lesser extent by the drilling process. Such signs are the concave downward appearance of many originally horizontal bedding planes, the haphazard mixing of lumps of sediment having differing lithologies, and the near fluid state of some sediments.

Coring disturbance is particularly noticeable in the upper 100 meters or so of soft, unlithified sediments. At the other extreme, well-consolidated sedimentary and igneous rocks can also be reduced to rubble by the coring process. Variations in lithology are not the only factors determining the amount of coring disturbance. Differences in the type of drilling bit used and drilling techniques employed are also important. Clearly too some sediment disturbance, and even some fracturing displayed by the cores, may be original predrilling features. Appendix I (Kidd, this volume) is devoted to the illustration and discussion of some types of disturbance encountered on Leg 42A.

\section{Artificial Stratigraphic Contacts}

When the drilling schedule called for spot coring, it was common practice on Leg $42 \mathrm{~A}$ to leave the core barrel in the drill string while "washing ahead." Ideally the circulating fluids should remove all the materials from the uncored interval. However, it often happened that some sediments from the uncored interval managed to get inside the core barrel. Consequently, an artificial contact between sediment from an uncored horizon and that from a cored interval was found, especially after a long period of "washing ahead." Under these circumstances the depth of the artificial contact was usually not taken as the true contact depth. Instead we tried to determine contacts in an uncored interval with the help of the driller's record of drilling characteristics together with careful examination of drilling artifacts such as downhole contaminants (debris slumped downhole), rocks dropped from the barrel of the previous core, etc. 


\section{SHIPBOARD SCIENTIFIC PROCEDURES}

\section{Numbering of Sites, Holes, Cores, Samples}

Drill site numbers run consecutively from the first site drilled by the Glomar Challenger in 1968, thus each site number is unique. A site refers to the hole, or holes, drilled while using one acoustic positioning beacon. Several holes may be drilled at a single locality by pulling the drill string above the sea floor ("mud line") and offsetting the ship some distance (usually $100 \mathrm{~m}$ or more) from the previous hole. This sometimes becomes necessary (as at Hole 373A) where there is insufficient soft sediment at the first location to "spud in" or bury the bottom-hole assembly (BHA).

The first (or only) hole drilled at a site takes the site number. Additional holes at the same site are further distinguished by a letter suffix. The first hole has only the site number; the second has the site number with suffix " $A$ "; the third has the site number with suffix "B"; and so forth. It is important for sampling purposes to distinguish the holes drilled at a site, since recovered sediments or rocks usually do not come from equivalent positions in the stratigraphic column at different holes.

Cores are numbered sequentially from the top down. In the ideal case, they consist of 9 meters of sediment or rock in a $6.6-\mathrm{cm}$-diameter plastic liner. In addition, a short sample is obtained from the core catcher (a multifingered device at the bottom of the core barrel which prevents cored materials from sliding out during core-barrel recovery). This usually amounts to about $20 \mathrm{~cm}$ of sediment and is stored separately. This sample, from each core, represents the lowest stratum recovered in the particular cored interval. The core-catcher sample is designated by CC (e.g., 378A-4, $\mathrm{CC}$, is the core-catcher sample of the fourth core taken in the second hole drilled at Site 3780).

The cored interval is the interval in meters below the sea floor measured from the point at which coring for a particular core was started to the point at which it was terminated. This interval is generally 9.5 meters (nominal length of a core barrel) but may be shorter if conditions dictate. Cores and cored intervals need not be contiguous. In soft sediment, the drill string ca.1 be "washed ahead" without recovering core by applying sufficiently high pump pressure to wash sediment out of the way of the bit. In a similar manner, a center bit, which fills the opening in the bit face, can replace the core barrel if drilling ahead without coring is necessary.

When a core is brought aboard Glomar Challenger, it is labeled and the plastic liner and core cut into 1.5meter sections. A full, 9-meter core would thus consist of six sections, numbered from the top down, 1 to 6 . (The discrepancy between the 9-meter core and 9.5meter core interval is discussed below.) Generally, somewhat less than 9 meters is recovered. In this case, the sections are still numbered starting with one at the top, but the number of sections is the number of 1.5 meter intervals needed to accommodate the length of core recovered; this is illustrated in Figure 3.

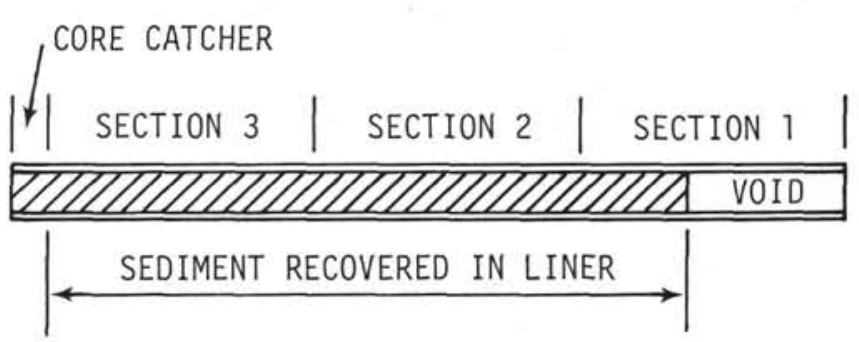

Figure 3. Numbering of core sections with incomplete recovery.

Thus, as shown, recovery of 3.6 meters of sediment would result in a core with three sections, with a void of 0.9 meter at the top of the first section. By convention, and for convenience in routine data handling at the Deep Sea Drilling Project, if a core contains a length of material less than the length of the cored interval, the sections that recovered material are placed in the top of the cored interval, with the top of Section 1 (not always the top of the sediment) located at the top of the cored interval. This is shown in in Figure 4 for the core in the above example. Thus, the depth below the sea floor of the top of the sediment of this hypothetical core would lie at 150.9 meters (not 150.0 $\mathrm{m}$ ) and the bottom at 154.5 meters (the core-catcher sample is regarded as being dimensionless).

It was noted above that a discrepancy exists between the usual coring interval of 9.5 meters and the 9 meter length of core recovered. The core liners used are actually 9.28 meters in length, and the core catcher accounts for another 0.2 meters. In cases where the core liner is recovered full to the top, the core is still cut into 1.5 meter sections, measured from the bottom of the liner, and the extra 0.28 meter section at the top is designated Section 0, or the "zero section." The zero section is ignored in calculations of depth below the sea floor of cores or levels within cores.

Samples taken from core sections are designated by the interval in centimeters from the top of the core section from which the sample was extracted; the sample size, in $\mathrm{cc}\left(\mathrm{cm}^{3}\right)$, is also given. Thus, a full sample designation would consist of the following information:

Leg (Optional)

Site

(Hole, if other than first hole)

Core Number

Section Number

Interval in centimeters from top of section

Site $378 \mathrm{~A}-1-2,122-124 \mathrm{~cm}$ (10-cc) designates a 10 cc sample taken from Section 2 of Core 1 from the second hole drilled at Site 378. The depth below the sea floor for this sample would then be the depth to the top of the cored interval ( $46 \mathrm{~m}$ in the example above) plus 3 meters for Sections 1 and 2, plus $122 \mathrm{~cm}$ (depth below the top of Section 3), or 50.2 meters. (Note, however, that subsequent sample requests should refer to a specific interval within a core section [in $\mathrm{cm}$ ] rather than level [m] below sea floor). 


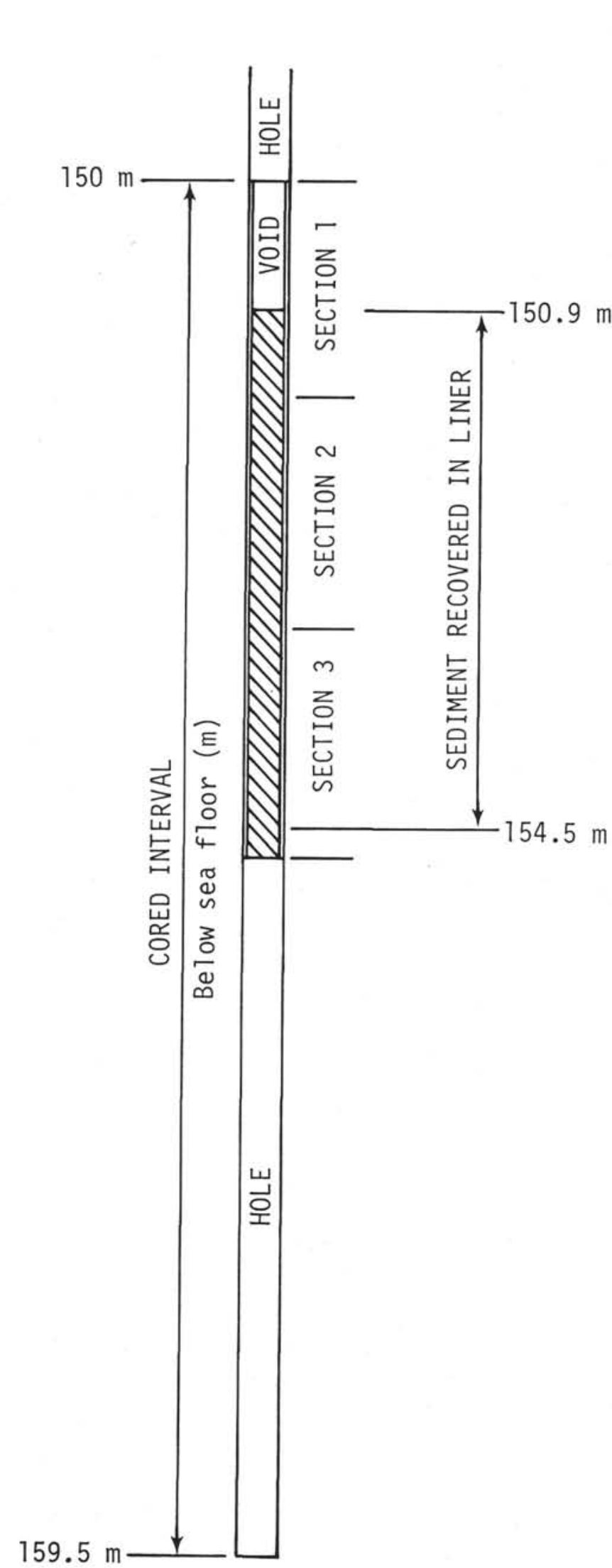

Figure 4. Position of incomplete sediment recovery within the cored interval.

\section{Handling of Cores}

The first analysis of the material recovered by an individual core is the core catcher. Rapid paleontological and lithological analysis of this material from the base of the cored interval is carried out in order to make decisions as to whether to drill ahead or to take another core.

After a core is brought up to the drill platform, it is cut, sealed, and labeled before beginning its routine progress through the shipboard analytical procedure. Often samples for organic geochemistry are taken at this stage.

In the core laboratory on Glomar Challenger, after physical property measurements requiring unsplit cores are made (such as thermal conductivity and densityporosity measurements using gamma ray attenuation techniques) the 1.5 -meter sections of sediment core and liner are split lengthwise. One-half is designated the "archive" half, which is described by the shipboard sedimentologists and photographed; and the other is the "working" half, which is sampled by both the shipboard sedimentologists and paleontologists for further shipboard and shore-based analysis. Almost all zero sections recovered on Leg $42 \mathrm{~A}$ were split and described.

Well-consolidated basalts and evaporite rocks were also split in half lengthwise, and great care was taken to maintain relative superposition of the sequences. Each piece of rock was numbered separately and arrows were drawn showing the uphole orientation on both sides prior to splitting. Furthermore, after description, photography, and sampling, each half-section was tightly encased in plastic tubing to avoid confusion due to subsequent handling.

\section{Sampling}

In the core laboratory samples for routine shorebased analysis such as grain size, X-ray minerology and total carbonate content were taken from the working half, labeled, and sealed. Because of the high level of pre-cruise interest in Leg 42A, samples were taken at this stage for numerous shore-based workers, whose contributions can be read in Part II of this volume. In addition, samples were regularly taken for immediate shipboard analysis, such as total carbonate by the "carbonate bomb" method. Routine samples were taken for smear slide, carbonate, grain size, and $\mathrm{X}$-ray analysis. The location of these samples is shown on the core forms in a column using appropriate symbols (see Sample Core Form, Figure 5). The working half was then sent to the paleontology laboratory, where samples for both shipboard and shorebased studies of nannofossils, foraminifers, Radiolaria, diatoms, silicoflagellates, and other fossil groups were taken.

Material obtained from core catchers, and not used up in the initial examination, was retained (in freezer boxes) for subsequent work. Sometimes pebbles particularly important to the interpretation of the site were extracted from the core and stored separately in labeled containers as a measure against loss. On occa- 
sions where the liners contained only sediment-laden water, the water was usually collected in a bucket, allowed to settle, and the residue was stored in freezer boxes. All samples are deposited in cold storage at the DSDP East Coast Repository at Lamont-Doherty Geological Observatory and are available to investigators.

\section{LITHOLOGIC STUDIES}

The archive half of the split section is used only for descriptive purposes. The cut surface of each is scraped to emphasize the sedimentary features and the color, texture, structure, and composition of the varying lithologies. Each section is described individually on a Visual Description Form. Smear slides are made and are examined using the shipboard petrographic microscopes. These, in conjunction with the "carbonate bomb" results, provide the basic shipboard information on lithology. The archive half is then photographed.

\section{Core Forms}

The basic descriptive data, both lithologic and biostratigraphic, for each section of a particular core are combined to produce the Core Summary Forms, which accompany each site chapter. These are first compiled aboard ship, but are upgraded later using postcruise shore-based data. A sample core form is illustrated in Figure 5. Most data are symbolized, but a short description is provided giving the essential lithologic information in the following order: Sediment or rock name, Sediment disturbance, Color name and Munsell or GSA number, Sedimentary structures and other special features, Composition from smear slides and bulk X-ray analysis, Grain size and carbonate data. Many cores contain important minor lithologies as well as a basic lithology. The description of the major lithology is so indicated in most cases; however, descriptive information for minor lithologies is included wherever possible.

As noted previously, the rotary drill-coring technique quite often results in disturbance of the cored sediments (see Appendix I). This is especially true of the softer unconsolidated sediments. A qualitative estimate of the degree of deformation is given as a symbol on the core logs (see Sample Core Form, Figure 5).

Color names and numbers are derived by reference to the GSA Rock Color Chart (Goddard et al., 1963). The reader is advised that colors recorded in core barrel summaries were determined during shipboard examination immediately after splitting core sections. Experience with carbonate sediments shows that many of the colors will fade or disappear with time, after opening and storage. Colors particularly susceptible to rapid fading are purple, light and medium tints of blue, light bluish-gray, dark greenish-black, light tints of green, and pale tints of orange. These colors change to white or yellowish-white or pale tan.

\section{Smear Slide Analysis}

Smear slides are prepared from minute amounts (1 or $2 \mathrm{~mm}^{3}$ ) of sediment taken with a spatula, puddled and smeared with distilled water on a glass slide, dried, and set under a cover-slip with Caedex. Their examination by petrographic microscope provides a rapid means of mineral identification. They are the basic source of lithologic information used onboard ship, although thin sections are used in studies of basalts and other hard rocks.

Smear slide estimates of mineral abundances are based on the percentage of the area of the smear slide covered by each component. Past experience has shown that accuracy may approach a percent or so for very distinctive minor constituents, but that for major constituents, accuracy of $\pm 10 \%$ is considered very good. The accuracy of this technique aboard ship is much enhanced when employed, as on Leg 42A, in conjunction with numerous carbonate bomb measurements (see below).

Of more importance than absolute accuracy to the sedimentologist are relative changes in component abundance. Consequently, although absolute percentages are used in the JOIDES classification scheme, only relative abundances are reported in the composition section of the Leg $42 \mathrm{~A}$ core forms, thus: D = Dominant, estimated as $75 \%$ to $100 \%$ of the total sediment; $\mathrm{A}=\mathrm{Abundant}$, estimated as $25 \%$ to $75 \%$ of the total sediment; $\mathrm{C}=\mathrm{Common}$, estimated as $5 \%$ to $25 \%$ of the total sediment; $\mathrm{R}=\mathrm{Rare}$, estimated as $1 \%$ to $5 \%$ of the total sediment; $\mathrm{T}=$ Trace, estimated as less than $1 \%$ of the total sediment.

Frequently sediment components from the same sample fall in the same abundance categories. On the core forms the listings of components from smear slides reflect in descending order of estimated abundance.

\section{"Carbonate Bomb" Data (B)}

During Leg 42A, extensive use was made of the "carbonate bomb" device (Muller and Gastner, 1971) as an aid in sediment classification. All total carbonate percentages measured by this method are recorded on the core summary forms, as are levels of sampling (B). Accuracy to within $\pm 5 \%$ total carbonate has been quoted for the device. However, postcruise shore-based studies suggest that it may be somewhat less accurate than this, particularly for high carbonate sediments or for complex mixtures of sedimentary components where carbonate is low (see below). Also the "bomb" device is probably considerably less accurate where dolomitic sediments are encountered.

At the Technische Universitat, Munich, shore base, 80 shipboard "bomb" measurements were checked by the LECO method using splits of the same suite of samples (from Sites 375 and 376). A systematic difference was observed between the results of the two techniques: (1) When $\mathrm{CO}_{2}$ pressure readings on the carbonate bomb were in the range 0.40 to 0.65 , both methods did give comparable values with a maximum difference of $\pm 5 \% \quad \mathrm{CaCO}_{3}$ (weight). (2) With $\mathrm{CO}_{2}$ pressure readings on the "bomb" in the range 0 to 40 , the LECO values were always higher, by $7 \%$ to $12 \%$ $\mathrm{CaCO}_{3}$ (weight) in the lower half of the range and by $1 \%$ to $7 \%$ (weight) in the upper part. (3) With $\mathrm{CO}_{2}$ pressure readings on the "bomb" above 0.65 the 


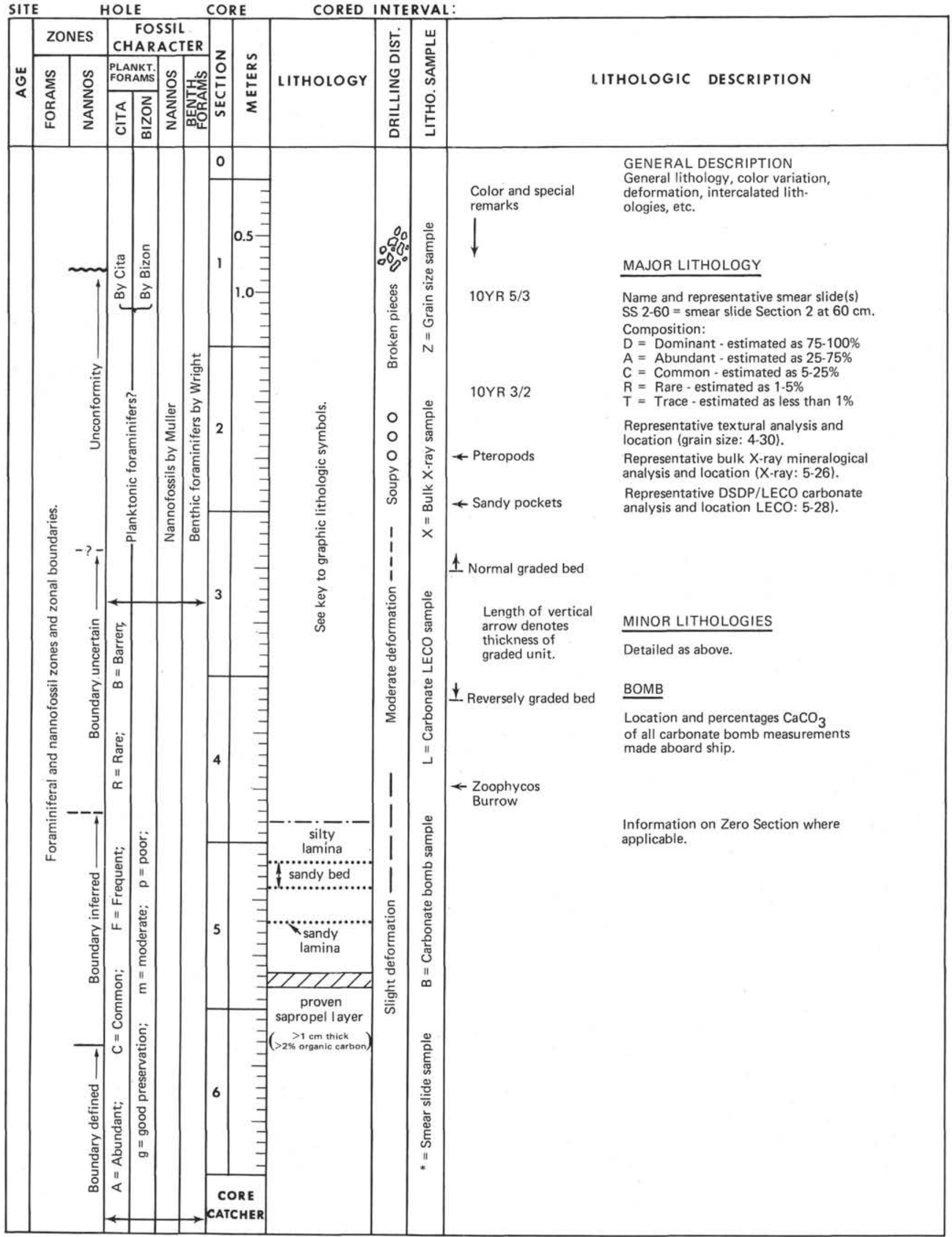

Figure 5. Sample core form. 


\author{
LECO values are always lower, by $1 \%$ to $13 \% \mathrm{CaCO}_{3}$ \\ (weight).
}

The LECO method (combustion by inductive heating in an $\mathrm{O}_{2}$ atmosphere) is considered more reliable than the "carbonate bomb" method. It is thought, by the Leg $42 \mathrm{~A}$ sedimentologists, that the systematic differences noted above probably could be reduced by the use of standardized sets of natural marine sediments of known $\mathrm{CaCO}_{3}$ content in the periodic calibration of the "bomb" device rather than synthetic $\mathrm{CaCO}_{3}$ as at present. The latter does not appear to yield a reliable calibration curve.

A scan of the $\mathrm{CaCO}_{3}$ values recorded on the core summary forms for both shipboard "carbonate bomb" and DSDP shore-based LECO measurements reflects the conclusions arrived at above. However, it is important to note that the "carbonate bomb" device is employed aboard Glomar Challenger primarily as an aid in the accurate naming of sediments in conjunction with the smear slide observations and that within the bounds of the JOIDES sediment classification, the discrepancies noted would not change the names given to sediments onboard ship.

Appendix II lists all carbonate bomb data for the Leg 42A drill sites together with the results of DSDP shore based LECO measurements. Plots of both, against depth in the hole, accompany the hole summary diagrams.

\section{Sediment Classification}

The sediment classification used on Leg 42A was devised by the JOIDES Panel on Sedimentary Petrology and Physical Properties, and adopted for use by the JOIDES Planning Committee in March 1974. It is reproduced in part below.

As allowed by the basic premises of the classification, the Leg $42 \mathrm{~A}$ sedimentologists often adopted additional descriptive terms and symbols to take account of the greater complexity of the Mediterranean sediments in relation to those of open ocean basins.

The only modification found necessary to the JOIDES classification itself was to the "Transitional Biogenic Calcareous Sediments" category; that is, the marls and marlstones $\left(>30 \% \mathrm{CaCO}_{3}\right.$ and $>30 \%$ slit and clay). The existing single symbol/category was split into five, taking into account dolomite content, and now includes: marls, marlstones, dolomitic marls, dolomitic marlstones, and dolomitic muds and mudstones.

\section{Lithologic Classification Scheme}

The following define compositional class boundaries and use of qualifiers in the lithologic classification scheme:

1).Compositional Class Boundaries

a) $\mathrm{CaCO}_{3}$ content (determined by carbonate bomb): 30 and $60 \%$. With a $5 \%$ precision and given the natural frequency distribution of $\mathrm{CaCO}_{3}$ contents in oceanic sediments, these boundaries can be reasonably ascertained.

b) Biogenic Opal Abundance (expressed as percent siliceous skeletal remains in smear slides): 10,30 , and $50 \%$. Smear slide estimates of identifiable siliceous skeletal material generally imply a significantly higher total opal abundance. The boundaries have been set to take this into account. c) Abundance of Authigenic Components (zeolites, Fe, and Mn micronodules etc.), fish bones, and other indicators of very slow sedimentation (estimated in smear slides); semiquantitative boundary: common $10 \%$. These components are quite conspicuous and a semiquantitative estimate is adequate. Even a minor influx of calcareous, siliceous, or terrigenous material will, because of the large difference in sedimentation rate, dilute them to insignificance.

d) Abundance of Terrigenous Detrital Material (estimated from smear slides): $30 \%$.

e) Qualifiers: Numerous qualifiers are suggested; the options should be used freely. However, components of less than $5 \%$ (in smear slide) should not be used as a qualifier except in special cases. The most important components should be the last qualifier. No more than two qualifiers should be used.

\section{Description of Sediment Types}

1) Pelagic Clay-Principally authigenic pelagic deposits that accumulate at very slow rates. The class is often termed brown clay, or red clay, but since these terms are confusing, they are not recommended.

a) Boundary with terrigenous sediments: Where authigenic components ( $\mathrm{Fe} / \mathrm{Mn}$ micronodules, zeolites), fish debris, etc. become common in smear slides. NOTE: Because of large discrepancy in accumulation rates, transitional deposits may be exceptional.

b) Boundary with siliceous sediments: $30 \%$ identifiable siliceous remains.

c) Boundary with calcareous biogenous sediments: Generally the sequence is one passing from pelagic clay through siliceous ooze to calcareous ooze, with one important exception: at the base of many oceanic sections, black, brown or red clays occur directly on basalt, overlain by or grading up into calcareous sediments. Most of the basal clayey sediments are rich in iron, magnanesse and metallic trace elements. For proper identification they require more elaborate geochemical work than is available on board. These sediments are placed in the "Special Rock" category, but care should be taken to distinguish them from ordinary pelagic clays.

2) Pelagic Siliceous Biogenic Sediments-These are distinguished from the previous category because they have more than $30 \%$ identifiable siliceous microfossils. They are distinguished from the following category by a $\mathrm{CaCO}_{3}$ content of less than $30 \%$. There are two classes: Pelagic biogenic siliceous sediments (containing less than $30 \%$ silt and clay); and transitional biogenic siliceous sediments (containing more than $30 \%$ silt and clay and more than $10 \%$ diatoms).

a) Pelagic biogenic siliceous sediments:

soft: Siliceous ooze (radiolarian ooze, diatomaceous ooze, depending on dominant component).

hard: radiolarite porcellanite

diatomite chert

(i) Qualifiers:

Radiolaria dominant: radiolarian ooze or radiolarite.

Diatoms dominant: diatom ooze or diatomite.

Where uncertain: siliceous (biogenic) ooze, or chert

(i) Qualifiers - In this group numerous qualifiers are possible usually based on minor constituent, for example: glauconitic, pyritic, feldspathic.

In the sand and sandstone category, conventional divisions such as arkose, graywacke, etc. are of course, acceptable, providing the scheme is properly identified. Clays, muds, silts, and sands containing $10-30 \% \mathrm{CaCO}_{3}$ shall be called calcareous.

b) Volcanogenic Sediments Pyroclastic rocks are described according to the textural and compositional scheme of Wentworth and Williams (1932). The textural groups are: Volcanic breccia $>32 \mathrm{~mm}$ Volcanic lapilli $\quad<32 \mathrm{~mm}$ Volcanic ash (tuff, if indurated) $<4 \mathrm{~mm}$ 
Compositionally, these pyroclastic rocks are described as vitric (glass), crystal or lithic.

c) Clastic sediments of volcanic provenance are described in the same fashion as the terrigenous sediments, noting the dominant composition of the volcanic grains where possible.

5) Special Rock Types-The definition and nomenclature of sediment and rock types not included in the system described above are left to the discretion of shipboard scientists with the recommendation that they adhere as closely as is practical to conventional terminology. Sources from which additional descriptive terminology was derived by Leg $42 \mathrm{~A}$ geologists are referenced in the text. In this category fall such rocks as:

Intrusive and extrusive igneous rocks

Evaporites; halite, anhydrite, gypsum (as a rock), etc.

Shallow water limestone (biostromal, biohermal,

coquina, oolite, etc.)

Dolomite

Gravels, congolomerates, breccias

Metalliferous brown clays

Concretions, barite, iron-manganese, phosphorite, pyrite, etc.

Coal, asphalt, sapropels (see below), and many others.

Two terms used in Part I of this volume warrant special mention:

\section{Sapropels}

Layers rich in organic carbon set in marine sediment sequences were first described from Mediterranean piston cores by Kullenberg (1952) and were referred to as "sapropelitic layers" by Olausson (1960-1961). Over subsequent years such layers have become known simply as "sapropels." On Leg $42 \mathrm{~A}$ it was recognized that large variations in organic carbon content were likely between layers and some distinction was necessary between true sapropels and less organic-rich sapropelic layers, as an aid to environmental interpretation (see Chapter 13). Furthermore, this special terminology should refer only to discrete layers (at least $1 \mathrm{~cm}$ thick) containing greater than $0.5 \%$ organic carbon content, within normal open marine pelagic sediment sequences. Thus diatomaceous organic-rich sediments within evaporitic sequences and thick sedimentary successions rich in organic carbon throughout do not qualify.

Consequently, dark layers encountered within normal pelagic sediments were subsequently given the following terminology, using the results of shore-based organic carbon measurements made at the DSDP La Jolla, Technische Universitat, Munich, and I.F.P., Paris shore-base laboratories:-

Greater than $2.0 \%$ organic carbon $=$ sapropel

$0.5 \%$ to $2.0 \%$ organic carbon $=$ sapropelic layer

Less than $0.5 \%$ organic carbon $=$ normal marine sediment (classified by the JOIDES scheme).

\section{Stromatolite}

Stromatolite is used throughout Part I of this volume to denote a sedimentary structure, a form of lamination which is frequently developed in anhydrite evaporitic rocks ("stromatolites"). They closely resemble certain modern and ancient laminated algal sediments (Garrison et al., this volume). However, identification of algal filaments is necessary to positively define environments. The structure was used only loosely as an environmental indicator aboard ship and shore-base studies were conducted to confirm the existence of algal filaments (Awramik, this volume).

\section{Lithologic Symbols}

Figure 6 displays the set of lithological symbols which accompany the JOIDES classification, including the modifications employed during Leg 42A. These symbols are used on the core summary forms and for illustrations throughout Part I of this volume.

\section{Hole Summary Diagrams}

For each hole a summary diagram is drawn and accompanies each site chapter. This is primarily a compilation of the lithologic and biostratigraphic data displayed on the core forms. Again these are initially drawn aboard ship and are later modified to take account of shore-base data. Downhole plots of carbonate content and X-ray mineralogical data, accompany each diagram.

\section{Lithostratigraphic Terminology}

Many different lithologies were encountered on Leg $42 \mathrm{~A}$. With the exception of our general use of the term "Mediterranean Evaporite Formation," no formal rock stratigraphic units are employed in the site chapters. The sediments are informally divided into units and subunits. For each site, these unit designations are outlined in a table in the lithology section and also in the appropriate hole summary diagram. Boundaries between specific units and subunits in cored intervals were both sharp and gradational. If a boundary occurred between cores, it was placed in the middle of the drilled interval, unless biostratigraphic evidence deemed otherwise.

\section{ROUTINE SHORE-BASED ANALYSES}

In a number of cases sediment names have been modified from those given aboard ship to take into account the shore-based data.

\section{Carbon-Carbonate Analyses}

Shore-based carbon-carbonate analysis, was with a LECO acid-base semiautomatic carbon determinator. Step-by-step procedures used at the DSDP La Jolla Laboratory are reported in Bader et al. (1970), and a discussion of the method, its calibration, and its precision can be found in Boyce and Bode (1972).

Total carbon and organic carbon (carbon remaining after treatment with hydrochloric acid) are determined in terms of weight percent, and the theoretical percentage of calcium carbonate is calculated from the following relationship:

Percent calcium carbonate $\left(\mathrm{CaCO}_{3}\right)=(\%$ total C $-\%$ C after acidification) $\times 8.33$.

However, carbonate sediments may also include magnesium, iron, or other carbonates; this may result in "calcium" carbonate values greater than the actual content of calcium carbonate. In DSDP 
Pelagic

Non-biogenic

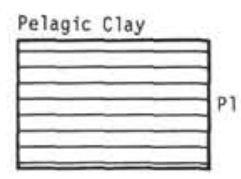

Siliceous Biogenic

Pelagic Siliceous Biogenic - Soft

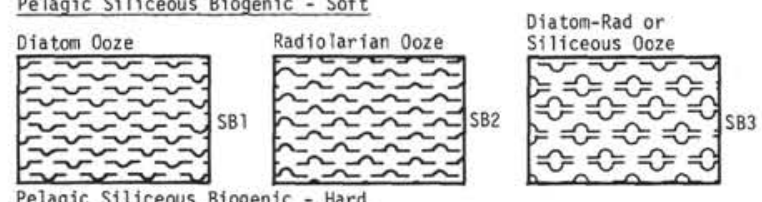

Pelagic Siliceous Biogenic - Hard
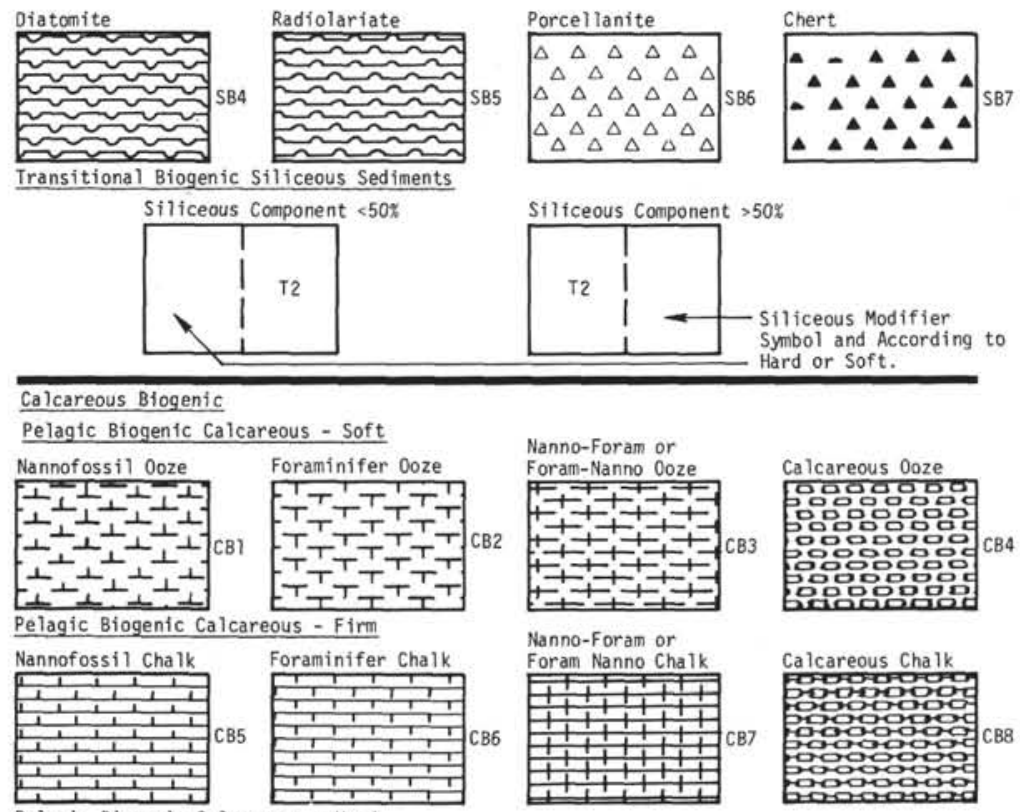

Pelagic Biogenic Calcareous - Hard

Limestone
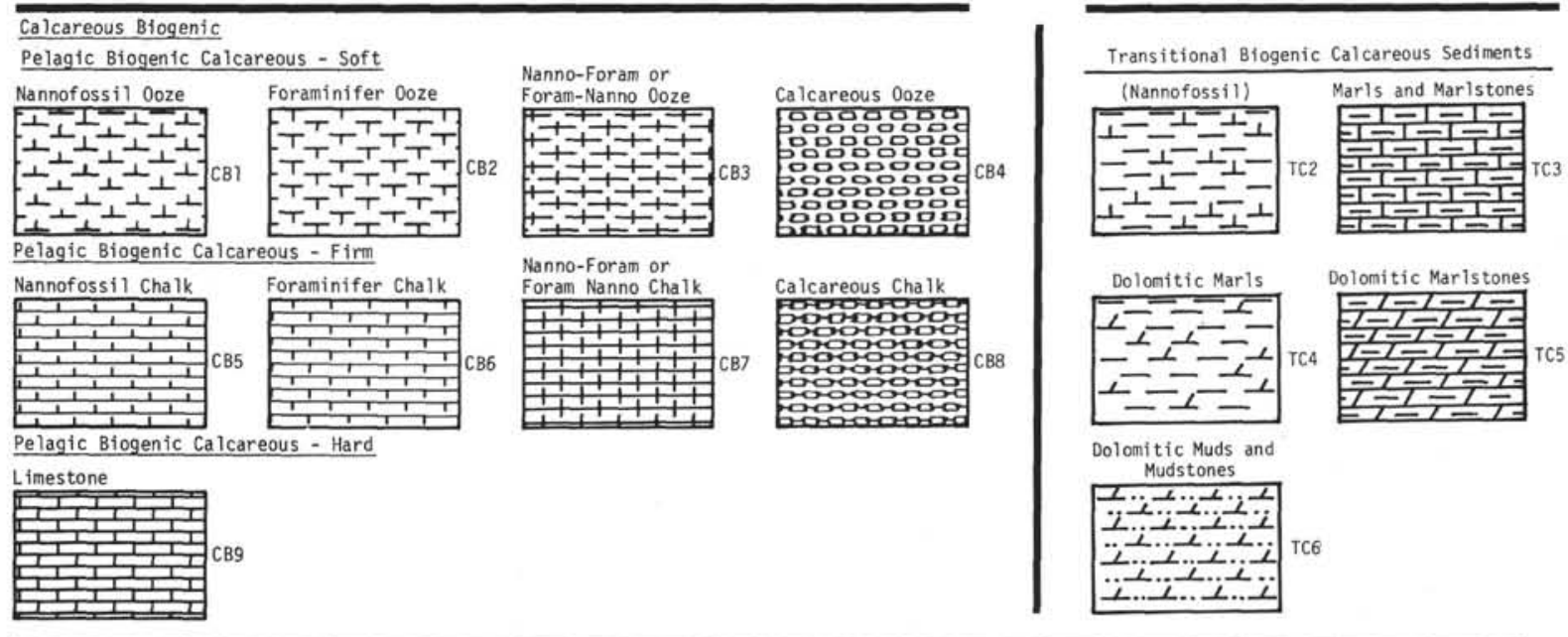

Terrigenous Sediments Qualifiers Letter Overprint (as per examples) Z Zeolite AT Glauconite A3 Siderite A4 (other may be designated)

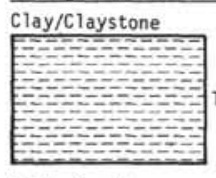

Silty Sand/
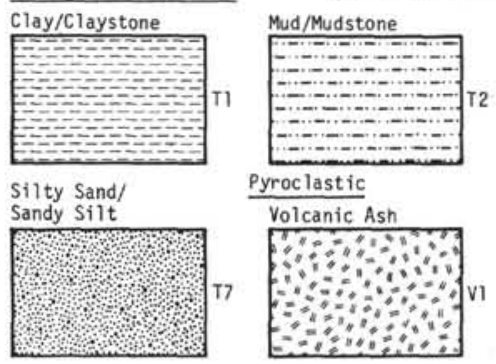

Pyroclastic

Volcanic Ash
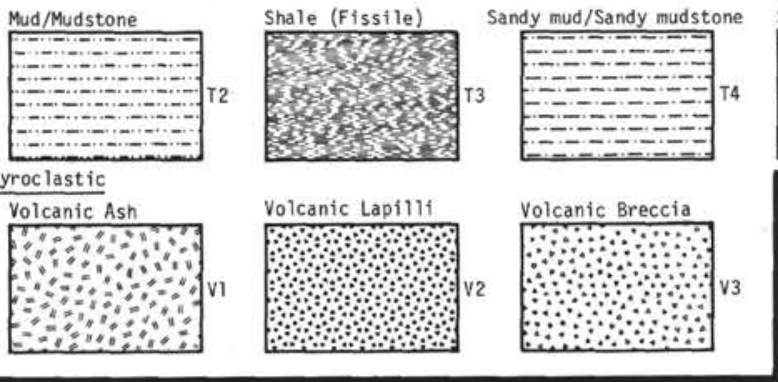

Special Rock Types
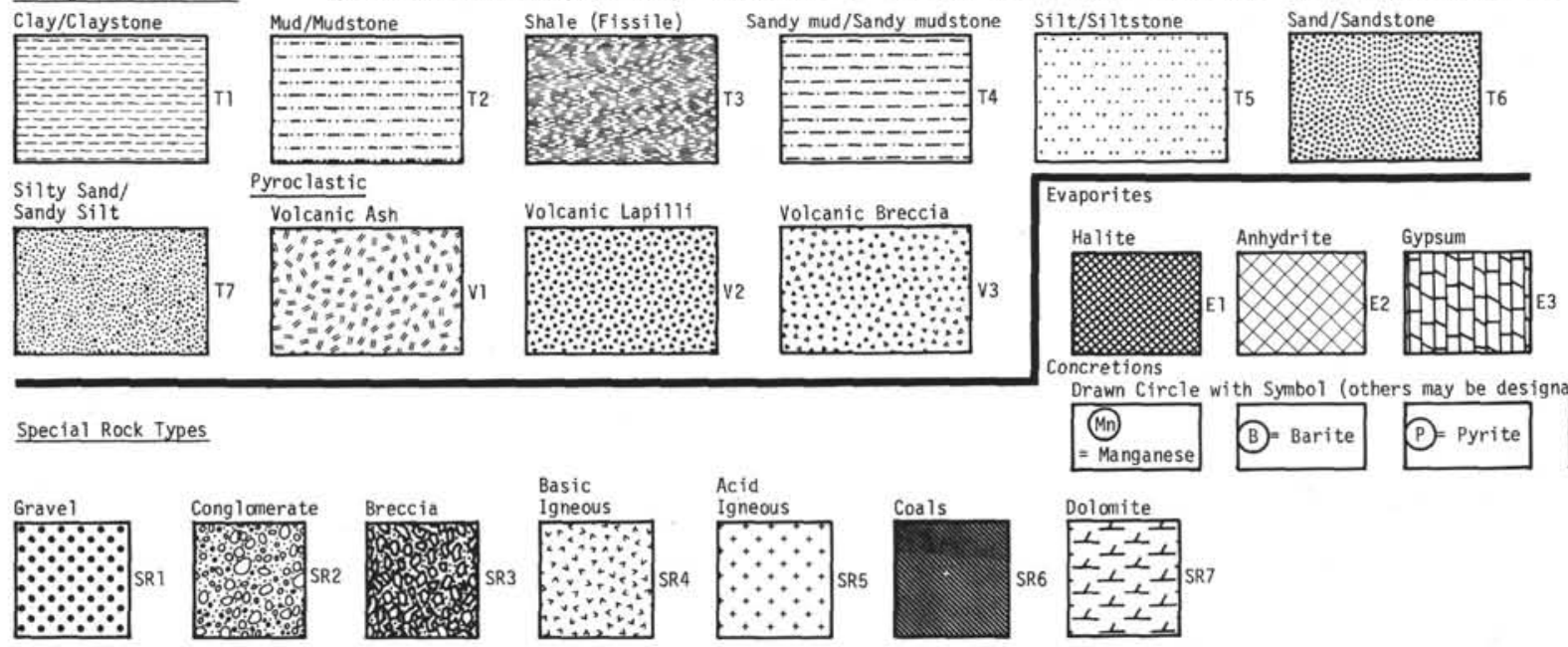

Drawn Circle with Symbol (others may be designated)

Figure 6. Graphic symbols to accompany the lithologic classification scheme used on Leg $42 \mathrm{~A}$. 
determinations, all carbonate is assumed to be calcium carbonate.

Precision of the determination is as follows:

Total carbonate (within 1.2 to $12 \%$ ) $= \pm 0.3 \%$ absolute

Total carbon (within 0 to $1.2 \%$ ) $= \pm 0.06 \%$ absolute

Organic carbon

Calcium carbonate

(within $10 \%$ to $100 \%$ )

(within 0 to $10 \%$ ) $= \pm 0.06 \%$ absolute

$= \pm 3 \%$ absolute $= \pm 1 \%$ absolute

Appendix II lists these data for Leg $42 \mathrm{~A}$, together with the results of carbonate bomb measurements, and all levels of sampling are displayed on the core forms with representative samples quoted. Plots accompany the hole summary diagrams.

\section{Grain Size Analyses}

The DSDP shore-based grain size analyses, presented on the core summary forms and in Appendix V, were derived by standard sieve and and pipette techniques, as described in detail in Bader et al. (1970), with modified settling times as in Boyce (1972).

\section{Bulk X-ray Mineralogical Analyses}

Bulk X-ray mineralogical analyses were made at the University of Paris shorebase (see Appendix III). Procedures are outlined in more detail in Mélières et al. (this volume). Quantitative measurements were made with an internal standard ( $\mathrm{Na} \mathrm{F}$ ) on material dried at $40^{\circ} \mathrm{C}$, without further processing such as washing in distilled water. The data are computed in percent of the crystalline fraction. Precision is considered to be $\pm 10 \%$. Trace amounts refer to percentages of less than $0.5 \%$. "Opal" percentages refer to opal CT in the sense of Jones and Segnit (1971), meaning a disordered mixture of cristobalite and tridymite. "Calcite" includes Mg-calcite where it occurs, while "dolomite" similarly includes Ca-dolomite. "Smectite" percentages are derived from the area of the expanded peak at $17 \AA$ under glycol. Because these analyses are of bulk mineralogy, pyrite which appears to be frequently present in the fine fraction on smear slides is rarely reported in listings on the core summary forms.

\section{GEOCHEMICAL MEASUREMENTS}

Shipboard geochemical measurements were routinely made during Leg 42A. The standard DSDP procedures for interstitial water and allied studies were employed. These are adequately described in Waterman (1970) and in Whitmarsh, Weser, Ross, et al. (1974).

\section{PHYSICAL PROPERTIES.}

Physical property measurements of bulk wet density, porosity, permeability, water content, compressional velocity, and shear strength were made during Leg $42 \mathrm{~A}$. The measurement techniques and sampling considerations have been carefully described (Boyce, 1973) and will only be outlined briefly in the following discussion. Further discussions of the routine physical property measurements, centering principally on cer- tain problems with the techniques and their effects on the quality of the data, can be found in a paper by Bennett and Keller (1973). Anyone intending to draw geologically relevant conclusions based on the physical property data presented in this volume is urged to read both papers. At drill sites where downhole temperature data were obtained, thermal conductivity measurements were made in order to permit calculation of the rate of heat flow through the sea floor. Methods of downhole temperature measurement are described in Erickson (this volume).

\section{Sonic Velocity Data}

Measurements of compressional wave velocities in sediments were made using the Hamilton frame apparatus (see Appendix VI, Table 1). All measurements were made at room temperature and pressure after the cores had reached thermal equilibrium with the laboratory, and soon after they were opened. Most of the data are obtained by measuring the length of time required for sound to traverse a path through the sediment and plastic core liner between a $400 \mathrm{kHz}$ acoustic transducer and receiver. This method assumes good acoustic contact between the liner and the sediment, a conditions which may not be fulfilled if the sediment does not completely fill the core liner. Corrections must be made to account for the thickness of the liner and the length of time required for the sound to pass through the liner. The corrections routinely applied presuppose liners of constant sound velocity and thickness. The second parameter, thickness, is known to vary widely from shipment to shipment and even within a given section of liner. Thus measurements of sound velocity of material in a split liner are subject to errors not present when measurements are made directly on material consolidated enough to be shaped and put between the transducers.

Where consolidation was sufficient, the ends and sides of chunks of unsplit core were cut or shaped into flat, parallel faces with normals parallel and perpendicular to the long axis of the core, taking care to minimize disturbance to the sample. The velocity was determiined directly on these chunks in both directions, and the horizontal and vertical velocities could then be compared in order to detect the presence of seismic anisotropy. (See Appendix VI, Table 2).

On Leg 42A, a substantial difference was found to exist between horizontal velocities (parallel to bedding) routinely measured through the liner in split cores, and the vertical velocities required to compute the thickness of sedimentary layers from travel time data. Thus it is clear that neglect of acoustic anisotropy can seriously affect realistic interpretation of seismic data from drilling results.

\section{Gravimetric Data}

Bulk property measurements were made on sediment samples obtained from the central, presumably undisturbed portion of the sediment cores using small $(<1 \mathrm{cc})$ syringe-type samplers and larger $(\approx 20 \mathrm{cc})$ 
stainless steel cylinders of known volume. The sediment samples were weighed wet and again after drying at $110^{\circ} \mathrm{C}$ for 24 hours and computations of bulk wet density, porosity, and water content were made (Appendix VI, Tables 3 to 5).

The extremely small volume of the syringe sample can result in substantial errors in measuring both weight and volume differences, and the small diameter of the syringe makes representative sampling of coarsegrained, highly porous and/or well-compacted sediments almost impossible. Comparison of the wet bulk density data taken with the two techniques indicates that the variability of the syringe data is much higher than that of data obtained using the cylinder-sampling technique. Further comparison of the syringe data with densities measured using the larger volume cylinder samples, as well as with densities determined by gamma ray attenuation methods, suggests that the syringe density data may be systematically low. The standard deviation of the syringe data is approximately twice as large as the standard deviations of the density values obtained using the other two measurement methods. Thus bulk-properties determined using syringe sampling techniques cannot be used to define any other than the most dramatic changes in sediment physical properties.

The larger volume of the samples obtained using the stainless steel cylinders permits a significant reduction in the errors in the volume and weight measurements. The sampling procedure was to push the sharpened end of a thin-walled cylinder of known weight and volume into the sediment until its lower end made contact with the curved wall of the core liner and its upper end was slightly buried beneath the surface of the freshly split core. Pliers were then used to gently rock the cylinder back and forth in order to break suction between the bottom of the sediment sample and the inside of the core liner. The cylinder was withdrawn with the sediment protruding from both ends and the sediment was carefully shaved and cut back until it was flush with the end of the cylinder. This ensured that the volume of sediment was the same as the previously measured internal volume of the cylinder. The sediment-filled cylinder was then weighed and dried for at least $24 \mathrm{hr}$ at $110^{\circ} \mathrm{C}$, after which it was weighed again.

Representative sampling was difficult in coarsegrained sediments due to the tendency for the larger grains to dig into the surface of the sample as the ends were being smoothed. In poorly compacted, plastic sediments the friction of the sediment plug against the inside of the cylinder tended to compress the plug or prevent it from entering the cylinder smoothly, thus causing some mechanical disturbance. In more compact sediments the cylinder tended to fracture the sediment before it had become fully inserted, or to break the plug loose from the remaining sediment in such a way that the ends of the plug did not protrude from, or even reach, the ends of the cylinder. In these cases where the volume was not accurately known the sample was only used to determine water content.
In sediments which could be sampled effectively, plexiglas plates were fastened over the ends of the cylinder to prevent drying, and the attenuation of gamma rays through both the plexiglas and the sample was determined, thus permitting calculation of the wet bulk density, on the basis of gamma ray attenuation data. In this way the bulk-wet density values obtained using both gravimetric and gamma ray attenuation techniques could be compared and the gamma ray attenuation technique could be calibrated using the more direct gravimetric data.

\section{GRAPE Data}

Measurement of the attenuation of a pencil-sized beam of gamma rays passing through a known thickness of sediment (or rock) permits calculation of the bulk wet density and porosity of the material. The accuracy of the method as applied to sediment or rock is strongly dependent upon the homogeneity, consistency, and dimensional stability of the sediment as it passes through the gamma ray beam. Because of coring disturbance and the mechanical properties of the sediment, it is common for very soft or very hard sediment to only partially fill the core liner. Often a core of relatively undisturbed sediment or rock will have a variable and smaller diameter than the inner diameter of the core liner. The length of the gamma ray path through both the sediment and through the air, water, or slurry between the sediment core and the walls of the core liner must be known in order to compensate for the effects of the varying geometry. Furthermore, the wet bulk density of the surrounding slurry, if any, must be measured separately using gravimetric techniques in order to correct for the presence of material other than the undisturbed portion of the core itself. All of these variables are difficult to estimate accurately and are time consuming to measure. If neglected, they can produce both highly variable and anomalously low values of wet bulk density values and high values of porosity. The most representative wet bulk density values for a particular type of sediment are probably the maximum values recorded. However, it is worth noting that the expulsion of interstitial fluids because of compaction during coring can produce higher wet bulk density values than the actual in situ density. Great care must be taken in drawing geological deductions from data obtained using the gamma ray attenuation technique.

\section{Shear Strength}

Measurements of the shear strength of sediment were made at only a few drill sites (Appendix VI, Table 6). The values were obtained by measuring the torque required to shear the sediment as it was applied to a four-bladed rectangular vane having known width and height. The method is capable of providing meaningful quantitative data for clayey sediments. However, when used for sediment types other than clays the interpretation of the data becomes much more qualitative. Because of the generally clastic nature of the sediments encountered during Leg $42 \mathrm{~A}$, the vane shear 
data presented should be considered of limited value as a basis for geological or engineering conclusions.

\section{Thermal Conductivity}

Thermal conductivity measurements were made in unconsolidated sediment cored at sites where downhole temperature data were obtained (Appendix VI, Table 7). The measurements were made using the transient needle-probe technique described by Von Herzen and Maxwell (1959). In this technique a hypodermic needle containing both a uniform heater wire having known electrical properties and a temperature sensing thermistor is inserted into the sediment through a hole drilled in the core liner. A known voltage is applied to the heater wire causing the needle to approximate a linear heat source. The temperature rise is monitored for about $5 \mathrm{~min}$ after heater turn-on and the rate of temperature increase thus derived, in conjunction with knowledge of the rate of heat release per unit length $(Q)$ of the needle, permits calculation of the thermal conductivity of a small, cylindrical volume of sediment immediately adjacent to the needle probe.

The temperature-time data were fitted to a curve of the form shown in Equation 1:

$$
\mathrm{T}(\mathrm{t})=\mathrm{A}+\mathrm{Bt}+\mathrm{C} \operatorname{In}(\mathrm{t})
$$

where $\mathrm{T}(\mathrm{t})$ is the temperature at time $t$ after the heater was turned on, and $A, B$, and $C$ are coefficients determined from a curve-fitting program. The $B t$ term in Equation 1 allows for a gradual linear temperature change with time to compensate for the combined effects of the approach of the core to room temperature, as well as variations in room temperature in the area where the cores are stored before and during the conductivity measurement. The $C$ coefficient along with the heat release per unit length $(Q)$ of the needle-probe is used to compute the thermal conductivity $K$ according to Equation 2:

$$
\mathrm{K}=\frac{\mathrm{Q}}{4 \pi \mathrm{C}}
$$

For heat-flow calculations, the thermal conductivity values obtained aboard ship must be corrected back to the in situ value corresponding to the pressure and temperature conditions beneath the sea floor. The temperature and pressure corrections $K T$ and $K_{\mathrm{p}}$ suggested by Ratcliffe (1960) were modified for use in boreholes, as shown in Equations 3 and 4:

$$
\begin{gathered}
\Delta \mathrm{K}_{\mathrm{T}}=\mathrm{K}_{\mathrm{obs}}\left(\mathrm{T}_{\mathrm{W}}+\mathrm{Z}_{\mathrm{H}} \cdot \frac{\mathrm{dt}}{\mathrm{dz}}\right) / 400 \\
\Delta \mathrm{K}_{\mathrm{p}}=\mathrm{K}_{\text {obs }}\left(\mathrm{Z}_{\mathrm{w}}+\mathrm{P}_{\text {sed }} \cdot \mathrm{Z}_{\mathrm{H}}\right) / 182900
\end{gathered}
$$

where

$K_{\text {obs }}=$ measured thermal conductivity $\left(\mathrm{mcal} / \mathrm{cm} \mathrm{sec}^{\circ} \mathrm{C}\right)$,

$T_{\mathrm{w}}$ = bottom water temperature $\left({ }^{\circ} \mathrm{C}\right)$,

$Z_{\mathrm{H}}=$ subbottom depth (m), $d T / d Z=$ average geothermal gradient $\left({ }^{\circ} \mathrm{C} / \mathrm{m}\right)$,

$T_{\mathrm{L}} \quad=$ core temperature at the beginning of measurement $\left({ }^{\circ} \mathrm{C}\right)$,

$Z_{\mathrm{w}} \quad=$ water depth $(\mathrm{m})$, and

$\rho_{\text {sed }}=$ average sediment density $(\mathrm{g} / \mathrm{cc})$.

The thermal conductivity values discussed in the site reports and listed in Table 7 of Appendix VI are the values measured at laboratory temperature and pressure. They have not been corrected to subbottom conditions.

\section{BIOSTRATIGRAPHY}

As a basic reference linking planktonic microfossil zonations to the absolute time scale, the Leg $42 \mathrm{~A}$ paleontologists used Ryan et al. (1974).

\section{Nannofossils}

Determination of the nannofossil zones for the Quaternary and Neogene sequences during Leg 42A was based on the standard nannoplankton zonation (Martini, 1971). Because of the particular development and history of the Mediterranean, some difficulty was encountered in determining zones in the middle and lower Miocene. Figure 7 shows the likely correlation of these zones with the planktonic foraminiferal zonation used on Leg 42A.

\section{Planktonic Foraminifera}

Two planktonic foraminiferal specialists were present in the Leg $42 \mathrm{~A}$ shipboard party. The reader is cautioned that, because the Mediterranean is an area in which planktonic foraminiferal biozonation is in a state of flux, the assignment of some boundaries and/or the interpretations derived from the biostratigraphy by these two workers can vary considerably. In general, however, it was agreed that for shipboard studies the Pliocene biozonation should be that proposed by Cita and the Miocene biozonation that proposed by Bizon. The Pliocene-Pleistocene biozonation used on Leg $42 \mathrm{~A}$ and its correlation with other published zonations are as shown in Figure 8. It is described in full in Cita (1975). The Miocene biozonation prepared for Leg $42 \mathrm{~A}$ by Bizon is outlined in Figure 9. The zonation follows as nearly as possible that for tropical areas (Caribbean) given in Bolli and Premoli-Silva (1973). The figure shows a general framework, and correlations with both Bolli and Premoli-Silva (1973) and

Blow (1969). It was used for the two deep holes drilled in the western and eastern Mediterranean (Sites 372 and 375 , respectively). It is possible to further subdivide some of the intervals at Site 372 , particularly the Globorotalia mayeri Zone, where representatives of the Globorotalia menardii group and Globorotalia miozea group are present and sometimes abundant. On the other hand, at Site 375 the sediments are generally too poor in planktonic foraminifer to use a more refined biozonation. 


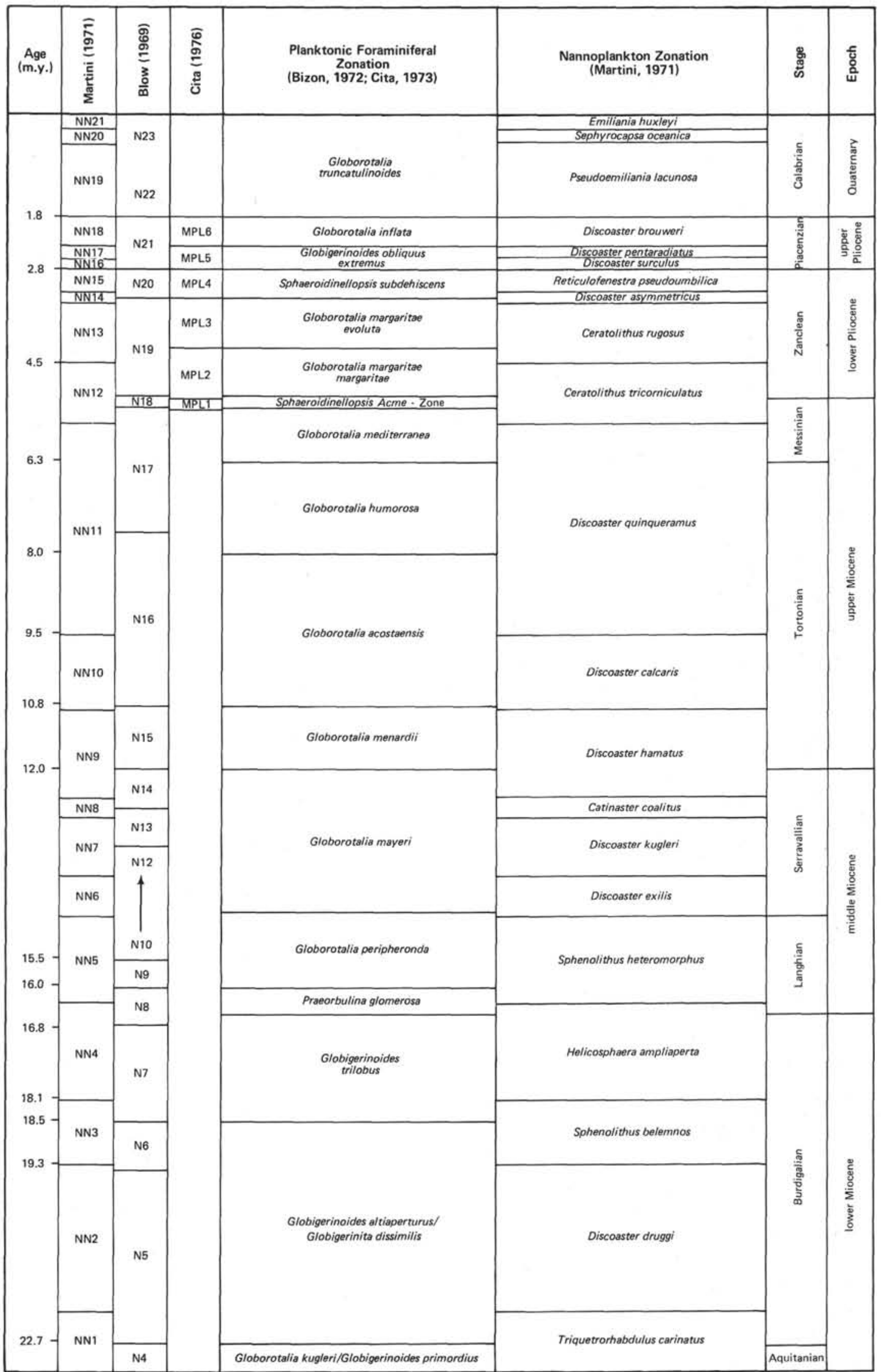

Figure 7. Correlation of the standard nannoplankton zonation (Martini, 1971) to the planktonic foraminiferal zonation used on Leg $42 \mathrm{~A}$. 


\section{Definition of Zones}

\section{Globorotalia kugleri/Globigerinoides primordius Zone}

Definition: Interval with zonal markers from the first occurrence of Globigerinoides primordius to the last occurrence of Globorotalia kugleri.

\section{Globigerinoides altiaperturus/Globigerinita dissimilis Zone}

Definition: Interval with zonal markers from the last occurrence of Globorotalia kugleri (or the first appearance of Globigerinoides altiaperturus) to the last occurrence of Globigerinita dissimilis and Globigerinitra unicaeris.

\section{Globigerinoides trilobus Zone}

Definition: Interval with zonal marker from the last occurrence of Globigerinita dissimilis and Globigerinita unicaeris to the first occurrence of Praeorbulina glomerosa. This interval corresponds roughly to the Globigerinatella insueta Zone of tropical areas.

\section{Praeorbulina glomerosa Zone}

Definition: Interval with zonal marker, from the first evolutionary occurrence of Praeorbulina glomerosa from Globigerinoides bisphericus-sicanus to the first evolutionary occurrence of Orbulina suturalis.

\section{Globorotalia fohsi peripheroronda Zone}

Definition: Interval with zonal marker, from the first evolutionary occurrence of Orbulina suturalis from Praeorbulina glomerosa to the last occurrence of Globorotalia fohsi peripheroronda, which occurs in the Caribbean area within the range of Globorotalia fohsi Zone.

\section{Globorotalia mayeri Zone}

Definition: Interval with zonal marker from the last occurrence of Globorotalia fohsi peripheroronda to the last occurrence of Globorotalia mayeri and Globorotalia siakensis.

\section{Globorotalia menardii Zone}

Definition: Interval with zonal marker from the last occurrence of Globorotalia mayeri and Globorotalia siakensis to the first occurrence of Globorotalia acostaensis. Globorotalia continuosa is generally well represented in this zone.

\section{Globorotalia acostaensis Zone}

Definition: Interval with zonal marker from the first evolutionary occurrence of Globorotalia acostaensis from Globortalia continuosa to the first evolutionary occurrence of Globorotalia humerosa from Globorotalia acostaensis. In this zone, the successive occurrences of Globorotalia pseudomioceanica and Globigerinoides obliquus extremus are observed.

\section{Globorotalia humerosa Zone}

Definition: Interval with zonal marker from the first evolutionary occurrence of Globorotalia humerosa from Globorotalia acostaensis to the first occurrence of Globorotalia margaritae/Sphaeroidinellopsis acme.

In the Mediterranean area, this interval can be subdivided into two subzones:

\section{Globorotalia humerosa Subzone}

Definition: Interval with subzonal marker from the first occurrence of Globorotalia humerosa to the first occurrence of Globorotalia mediterranea.

\section{Globorotalia mediterranea Subzone}

Definition: Interval from the first occurrence of Globorotalia mediterranea to the first occurrence of Globorotalia margaritae/Sphaeroidinellopsis acme. The upper part of this zone can be clearly recognized in southern Spain (Bizon and Montenat, in press) where evaporites are not always present.

\section{Benthic Foraminifers}

Analyses of benthic foraminiferal assemblages were the primary source of paleobathymetric information collected during Leg 42A (Wright, this volume). It is important to record here some explanation of the bathymetric terms and zonation employed.

The conventional bathymetric zonation of the ocean floor is based on bottom configuration and the depth at which certain biologically significant phenomena occur. This zonation is discussed by Hedgepeth (1957) and Ingle (1973). Unfortunately, the Mediterranean Sea is topographically and hydrographically unlike the open ocean basins of the world. In particular, the hypsographic curve of the Mediterranean is significantly different from that of the world's oceans (Figure 10) and the character and position of water masses in the Mediterranean differs from their counterparts in the open ocean basins (Nielsen, 1912). Therefore, the paleobathymetry of Leg $42 \mathrm{~A}$ sites is based on a bathymetric zonation designed specifically for the Mediterranean Sea, by reference to its own hypsographic curve, and on the benthic foraminferal distribution within the Mediterranean itself (Parker, 1958; Cita and Zocchi, in press). This zonation is given in Table 2 below.

TABLE 2

Bathymetric Zonation used on Leg 42A

\begin{tabular}{lcc}
\hline \multicolumn{1}{c}{ Zone } & Upper Limit (m) & Lower Limit (m) \\
\hline Inner Neritic & 0 & 50 \\
Outer Neritic & 50 & $150-200$ \\
Upper Epibathyal & $150-200$ & $500-700$ \\
Lower Epibathyal & $500-700$ & $1000-1300$ \\
Upper Mesobathyal & $1000-1300$ & 1800 \\
Mid Mesobathyal & 1800 & 2500 \\
Lower Mesobathyal & 2500 & 4000 \\
Infrabathyal & $>4000$ & \\
\hline
\end{tabular}




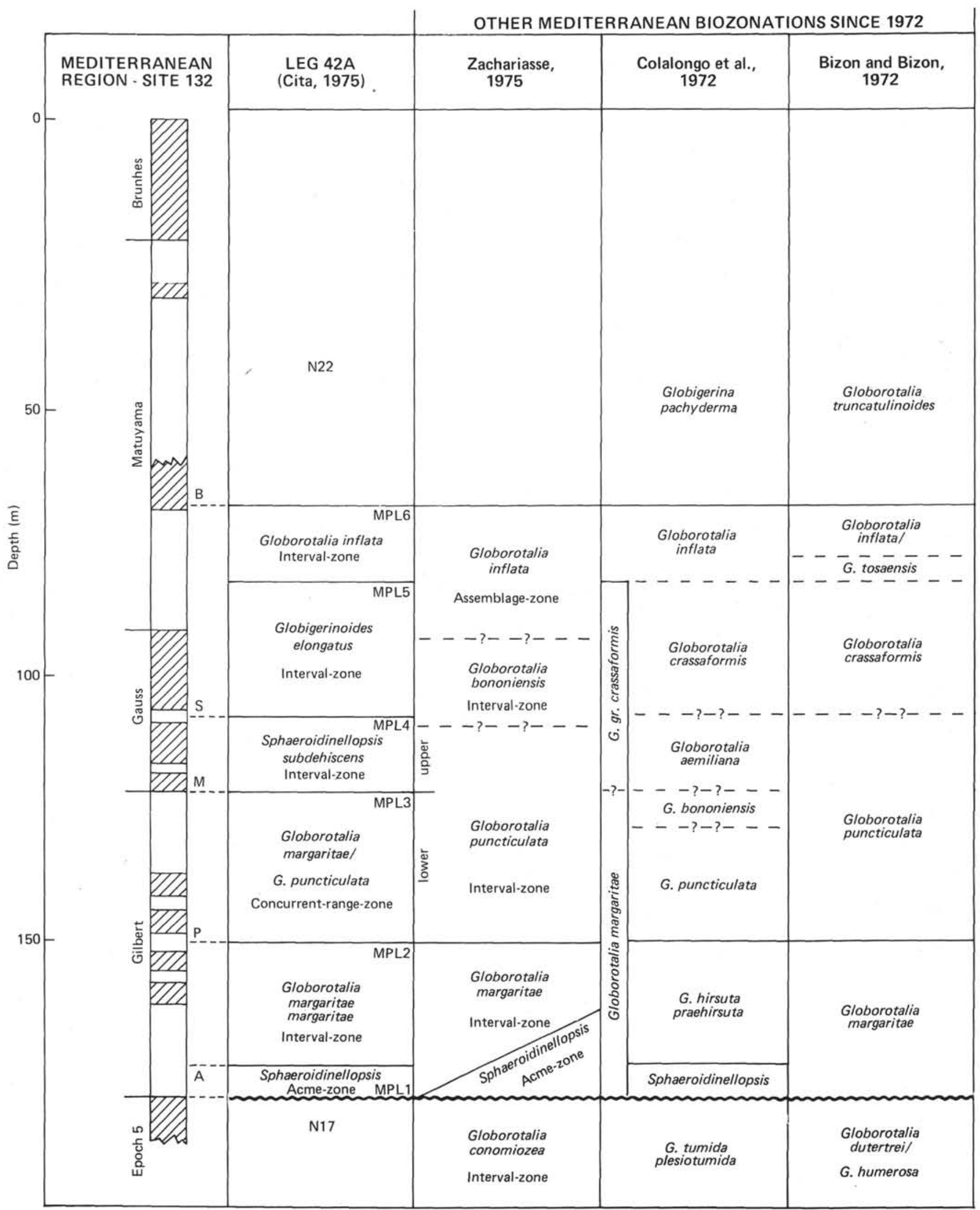

Figure 8. Correlation of the planktonic foraminiferal biozonation used for the Pliocene and Pleistocene on Leg $42 \mathrm{~A}$ (from to the left shows the paleomagnetic interpretation of DSDP Site 132. Next column locates datum planes recognized either $B=$ extinction horizon of Discoaster brouweri; $S=$ extinction horizon of Sphaeroidinellopsis; $M=$ extinction horizon of which are considered biostratigraphically well founded and which are calibrated to the paleomagnetic stratigraphy. Dashed magnetic stratigraphy. Dashed lines with question marks indicate correlations biostratigraphically uncertain and which are 


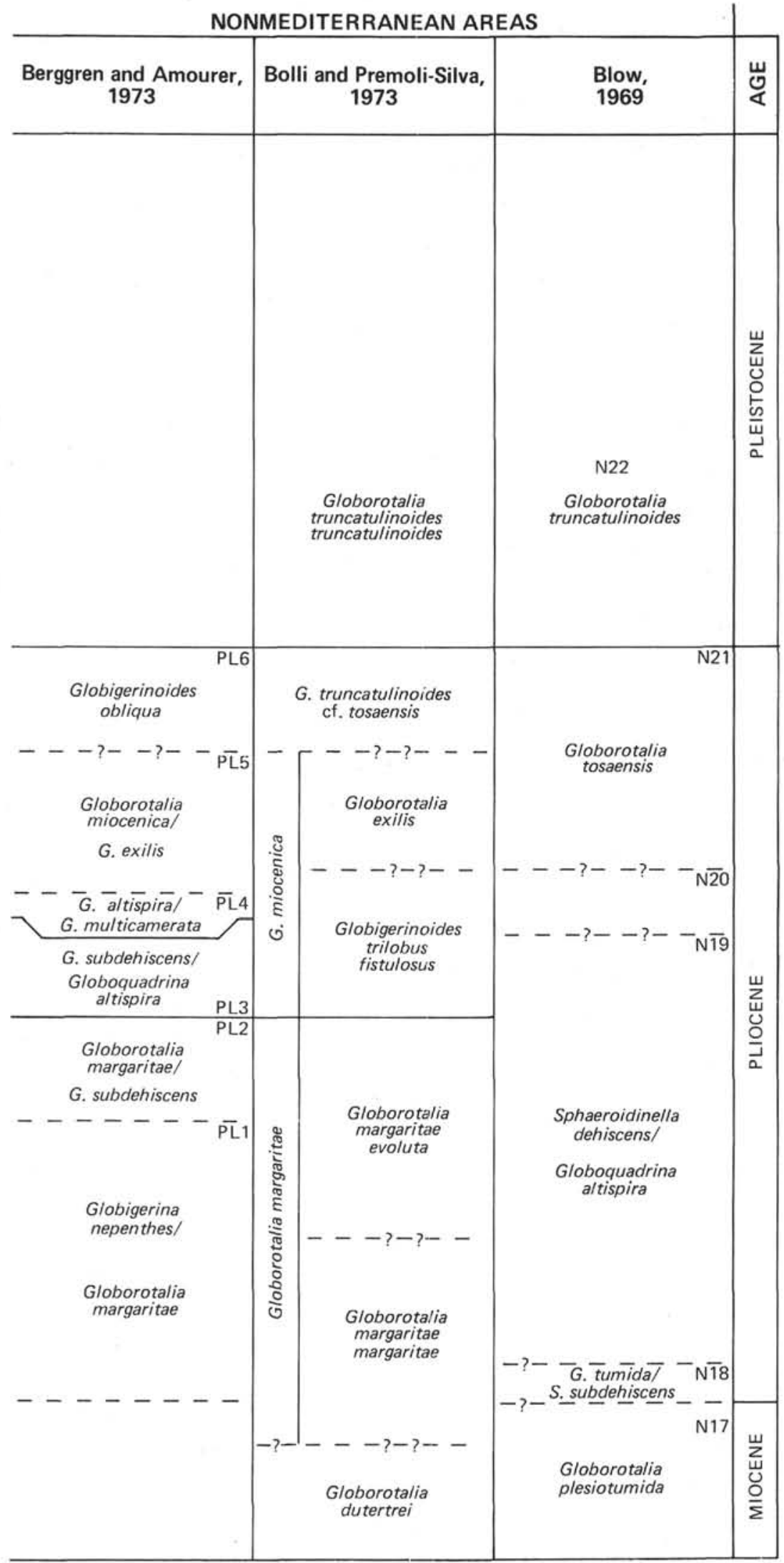

Cita, 1975) with other biozonations proposed since 1972, for the Mediterranean and for non-Mediterranean areas. The column at Site 132, or in the Capo Rossello section, or in both, and discussed in her text. From top to bottom, they are as follows: Globorotalia margaritae; $P=$ Globorotalia puncticulata datum; $A=$ Ceratolithus acutus datum. Solid lines indicate correlations lines indicate correlations which are considered biostratigraphically well founded, but which are not calibrated to the paleonot calibrated paleomagnetically. 
Correlations after Postuma, 1971

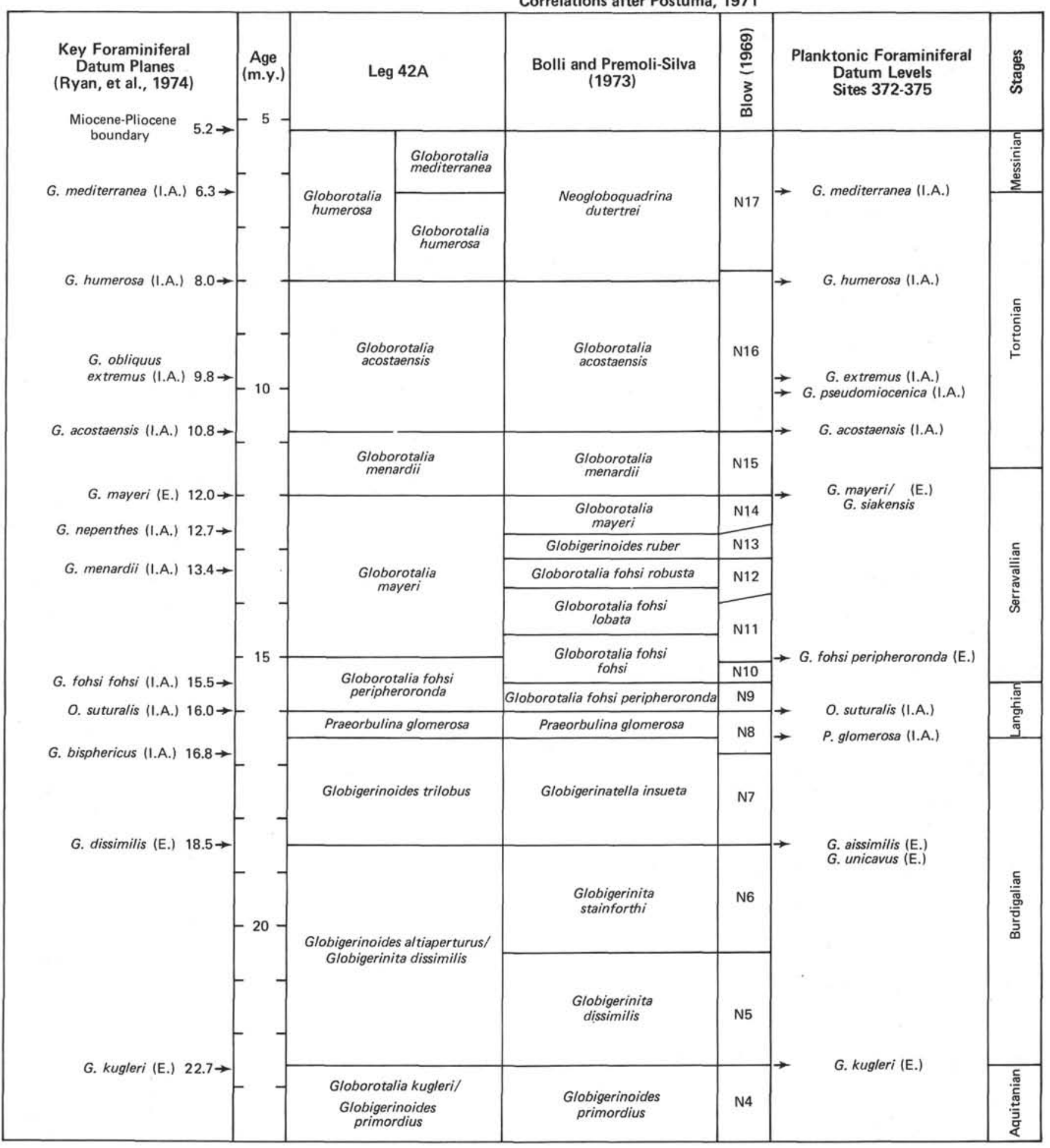

Figure 9. Miocene biozonation with planktonic foraminiferal datum planes used on Leg $42 \mathrm{~A}$ and its correlation to other biozonations by Bolli et al., 1973 and Blow, 1969. 


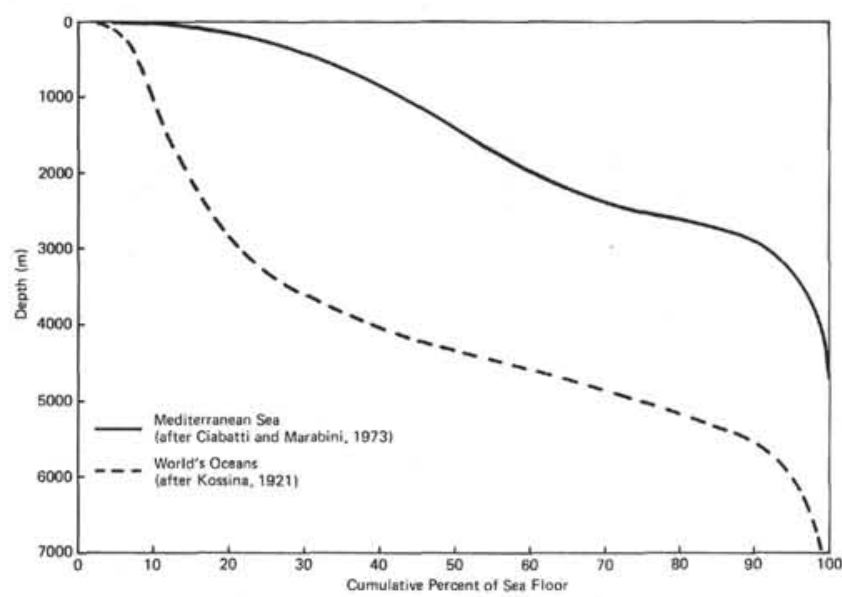

Figure 10. Hypsographic curves for the Mediterranean and the open ocean basins.

\section{REFERENCES}

Bader, R. G. et al., 1970, Initial Reports of the Deep Sea Drilling Project Volume 4, Washington (U.S. Government Printing Office), Appendix III p. 745-753.

Bennett, R. H. and Keller, G. H., 1973, Physical properties evaluation, In Van Andel, T. H., Heath, G. R., et al., Initial Reports of the Deep Sea Drilling Project, Volume 16; Washington (U.S. Government Printing Office), p. 513-519.

Blanc-Vernet, L., 1969. Contribution a l'etude des Foraminiferes de Mediterranee: Extr. Recueil Trav. Stat. Mar. D'Endoume, Bull. 64-48, p. 1-281.

Berggren, W. A. and Amdurer, M., 1973. Late Paleogene (Oligocene) and Neogene planktonic foraminiferal biostratigraphy of the Atlantic Ocean (Lat. $30^{\circ} \mathrm{N}$ to Lat. $30^{\circ} \mathrm{S}$ ); Riv. Ital. Paleont. Strat., v. 79 , p. 337-392.

Bizon, J. J. and Bizon, G., 1972. Atlas des principaux Foraminiferes planctoniques du bassin Mediterranean, Oligocene a Quaternaire; Eol. Techniq, Paris, p. 1-316.

Blow, W. H., 1969. Late middle Eocene to Recent planktonic foraminiferal biostratigraphy: 1st Intern. Conf. Plankt. Microfossils Proc. (Geneva, 1967), p. 199-421.

Bolli, H. M. and Premoli-Silva, I., 1973. Oligocene to Recent planktonic foraminifera and stratigraphy of the Leg 15 sites in the Caribbean, In Edgar, N.T., Saunders, J. B., et al., Initial Reports of the Deep Sea Drilling Project, Volume 15: Washington (U.S. Government Printing Office), p. 475-498.

Boyce, R. E., 1972. Grain size analyses, Leg 9. In Hays, J. D. et al., Initial Reports of the Deep Sea Drilling Project, Volume 9: Washington (U.S. Government Printing Office), p. 779-798.

1973. Physical properties - methods. In Edgar, N. T., Saunders, J. B., et al., Initial Reports of the Deep Sea Drilling Project, Volume 15; Washington (U.S. Government Printing Office), p. 1115-1127.

Boyce, R. E., and Bode G. W., 1972. Carbon and carbonate analyses, Leg 9 Deep Sea Drilling Project. In Hays, J. D., et al., Initial Reports of the Deep Sea Drilling Project, Volume 9: Washington (U.S. Government Printing Office), p. 797-816.

Cita, M. B., 1975. Planktonic foraminiferal biozonation of the Mediterranean Pliocene deep sea record: A Revision: Riv. Ital. Pal. Strat., v. 81 .
Cita, M. B. and Zocchi, M., in press. Distribution patterns of benthic foraminifera on the floor of the Mediterranean Sea: Micropaleontol., Spec. Publ..

Colalongo, M. L., Padovani, A., Sartoni, S., Tampieri, R., D'Onofrio, S., Elmi, C., Francavilla, F., Manzoni, M., Poluzzi, A., and Russo, A., 1972. Biostratigrafia e cronostratigrafia del Pliocene: Boll. Soc. Geol. Ital. v. 91, p. 489510.

Goddard, E. N., et al., 1963. Rock Color Chart: New York (Geol. Soc. Am.).

Hedgepeth, J. W., 1957. Classification of marine environments: Geol. Soc. Am. Mem. 67, v. 1, p. 17.

Ingle, J. I., Jr., 1973. Neogene foraminifera from the Northeastern Pacific Ocean, Leg 18, Deep Sea Drilling Project. In Kulm, L. D., von Huene, R., et al., Initial Reports of the Deep Sea Drilling Project, Volume 18: Washington (U.S. Government Printing Office), p. 517-567.

Jones, J. B. and Segnit, E. R., 1971. The nature of opal, in Nomenclature and constituent phases: J. Geol. Soc., Australia, v. 18, p. 57-68.

Kullenberg, B., 1952. On the salinity of the water contained in marine sediments; Medd. Oceanografiska Inst. Goteborg, v. 21.

Martini, E., 1971. Standard Tertiary and Quaternary calcareous nannoplankton zonation, In Forinall, A. (Ed.) Second Plankt. Conf. Proc., Roma 1970, Rome (Teenoscienza), p. 739-785.

Matthews, D. J., 1939. Tables of the velocity of sound in pure water and in seawater: Hydrographic Department, Admiralty, London.

Mélières et al., 1977. Leg 42A: X-ray Mineralogical Studies: this volume.

Müller, G. and Gastner, M., 1971. The "Karbonate Bombe;" A Simple Device for the Determination of the Carbonate Content in Sediments, Soils and Other Materials; N. Jb. Miner. Mh., v. 10, p. 466-469.

Nielsen, J. N., 1912. Hydrography of the Mediterranean and adjacent waters: Rep. Danish Oceanogr. Exp. Medit., v. 1, p. 77-192.

Olausson, E., 1960. Description of sediment from the Mediterranean and the Red Sea; Rept. Swedish Deep-Sea Exped., 1947-48, v. 8, p. 287.

1961, Studies of deep sea cores. Sediment cores from the Mediterranean Sea and the Red Sea: Rept. Swedish Deep-Sea Exped., 1947-48, v. 8, p. 337.

Parker, F. L., 1958. Eastern Mediterranean Foraminifera: Rept. Swedish Deep-Sea Exped., v. 8, p. 217-285.

Postuma, J. A., 1971. Manual of planktonic foraminifera: New York, Elsevier Publ. Co., p. 1-420.

Ratcliffe, E. H., 1960. The thermal conductivities of ocean sediments: J. Geophys. Res., v. 65, p. 1535-1541.

Ryan, W. B. F., Cita, M. B., Dreyfus, M., Rawson, L. H., Burkle, and Saito, T., 1974. A paleomagnetic assignment of Neogene stage boundaries and the development of isochronous datum planes between the Mediterranean, the Pacific and Indian Oceans in order to investigate the response of the World Ocean to the Mediterranean "Salinity Crisis": Riv. Ital. Pal., v. 80, p. 631-688.

Von Herzen, R. and Maxwell, A. E., 1959. The measurement of thermal conductivity of deep sea sediments by a needle-probe method: J. Geophys. Res., v. 64, p. $1557-$ 1563.

Waterman, L. S., 1970. Interstitial water program, Shipboard Manual: Deep Sea Drilling Project Manuscript Report, May 1970: Scripps Institution of Oceanography, p. 141. 
Wentworth, C. K., 1922. A scale of grade and class terms of clastic sediments, J. Geol., v. 30, p. 377.

Wentworth, C. K. and H. Williams, 1932. The classification and terminology of the pyroclastic rocks; Rept. Comm. Sed. Nat. Research Council, Bull. No. 89, p. 19-53.

Whitmarsh, R. B., Weser, O. E., Ross, D. A., et al., 1974.
Explanatory notes. In Initial Reports of the Deep Sea Drilling Project, Volume 23: Washington (U.S. Government Printing Office), p. 20-29.

Zachariasse, W. J., 1975. Planktonic foraminiferal biostratigraphy of the late Neogene of Crete (Greece): Utrecht Micropal. Bull. 11, p. 1-171. 